\title{
LOKALIZÁCIA NAJSTARŠIEHO SAKRÁLNEHO PRIESTORU V KOSTOLE SV. MIKULÁŠA V BRATISLAVE - PODUNAJSKÝCH BISKUPICIACH (VÝSLEDKY ARCHEOLOGICKÉHO VÝSKUMU)
}

\author{
PETRA ŠIMONČIČOVÁ KOÓŠOVÁ - PAVOL PAULINY - RÓBERT ERDÉLYI - BARBORA \\ VACHOVÁ - ANDREJ BOTEK - DANIEL PIVKO - IGOR MURÍN
}

\begin{abstract}
Abstrakt: V rokoch 2015-2018 prebehli tri sezóny archeologického výskumu Kostola sv. Mikuláša v Bratislave-Podunajských Biskupiciach. Ich ciel'om bolo zachytit'stavebné fázy kostola a identifikovat' najstaršiu sakrálnu stavbu v skúmanom priestore. Súčasne prebiehal architektonicko-historický i reštaurátorský výskum, ktorých výsledky sa navzájom dopĺn̆ali. V predloženej štúdii sa zameriavame na archeologicky zachytené najstaršie horizonty 11. až 13. storočia, t. j. po vznik súčasného pôdorysu trojlod’ového kostola s polygonálnym presbytériom. Výsledky sú doplnené petrografickou analýzou, ktorá dokladá sekundárne použitie staršieho stavebného materiálu a výsledkami geofyzikálneho prieskumu, na základe ktorého bola identifikovaná jedna zo sledovaných stavebných fáz.
\end{abstract}

Kl'účové slová: sakrálna architektúra - cintorín-esovité záušnice-petrografia-11.-13. storočie.

The location of the oldest sacred space in the Church of St. Nicholas, Bratislava-Podunajské Biskupice (Results of archaeological research)

Abstract: Archaeological research into the Church of St. Nicholas in Bratislava - Podunajské Biskupice was conducted in the years 2015-2018. The main objective was to determine the building phases of the church and to identify the oldest sacred structure in the investigated space. In parallel, architecturalhistorical and restoration research was carried out, the results of which complemented those of the excavations. This study focuses on the archeologically detected oldest horizons from the 11th-13th centuries, i.e. before the origination of the present ground plan of the triple-nave church with a polygonal presbytery. The results are supplemented by a petrographic analysis which confirmed secondary use of older building material, and by the results of geophysical survey on the basis of which one of the observed building phases was defined.

Key words: sacred architecture-churchyard -S-shaped earrings-petrography-11th-13th centuries.

Areál Kostola sv. Mikuláša je ohradený a nachádza sa na miernej vyvýšenine v centre niekdajšej obce, dnes mestskej časti Bratislavy, Podunajské Biskupice (obr. 1). V stredoveku sa tu sformovala poddanská dedina patriaca ostrihomskému arcibiskupovi. Ten bol zároveň, až do roku 1912, patrónom Kostola sv. Mikuláša. Na pravom brehu Dunaja sa majetky ostrihomského arcibiskupa, resp. kapituly, po prvý raz spomínajú v roku 1264, kedy pápež Urban IV. daroval Kostol sv. Mikuláša v Biskupiciach na Žitnom ostrove, predtým patriaci magistrovi Gerhardovi z Parmy, kaplánovi Štefana Váncsaiho (Botek-Erdélyi-Pauliny-Vachová 2015, 6, 54). Od roku 1390 boli Podunajské Biskupice uvádzané ako exemptná farnost'. Po získaní privilégií v 16. storočí bola dedina povýšená na zemepanské mestečko. Vyberalo sa tu mostné mýto pri brode (SPS, 493; Horváth 1990, 228; Polla-Vallašek 1991, 120; Botek-Erdélyi-Pauliny-Vachová 2015, 54; 2016, 175).

Súčasná dispozícia Kostola sv. Mikuláša je pät'lod’ová s polygonálne ukončenou svätyňou a jednou vežou na západnej strane. V staršej literatúre sa kladie prvá zmienka o kostole do roku 1221 (SPS, 494; Polla-Vallašek 1991, 120). Archívny výskum (P. Buday) súvisiaci s pamiatkovou obnovou presbytéria uvádza ako prvú overenú zmienku až vyššie spomenutý záznam z roku 1264 (Botek-Erdélyi-Pauliny-Vachová 2015, 54).

\section{Východiskové hypotézy}

Pred začiatkom obnovy a realizácie výskumov v Kostole sv. Mikuláša sme vychádzali z doteraz známych poznatkov čerpajúcich zo Súpisu pamiatok na Slovensku (1968) a zápiskov Václava Mencla. V. Mencl datoval vežu, lod', presbytérium i sakristiu kostola na prelom 


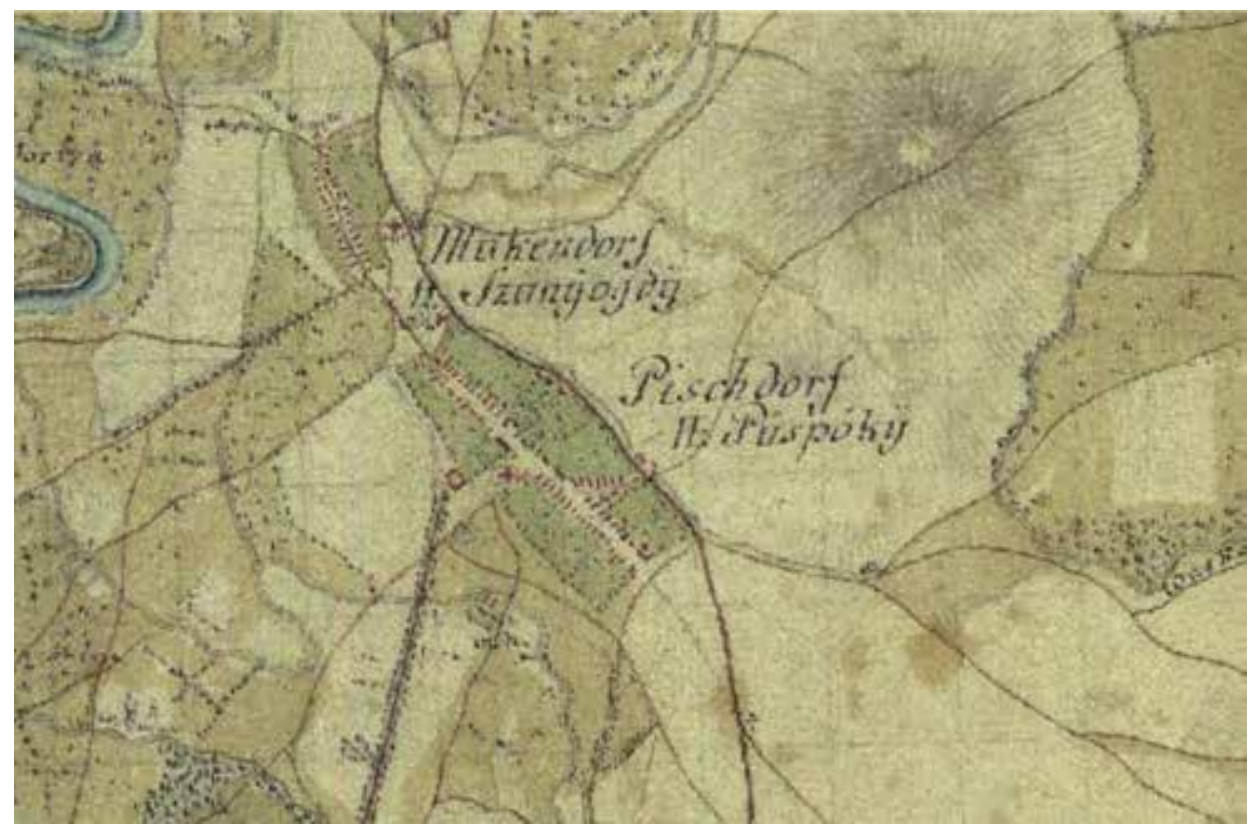

Obr. 1. Podunajské Biskupice na 1. vojenskom mapovaní (1764-1768).

Abb. 1. Podunajské Biskupice auf der 1. Militärischen Kartierung (1764-1768).

13. a 14. storočia a zaklenutie gotickou krížovou klenbou okolo roku 1340. Novodobé prístavby neboli predmetom jeho záujmu. Súpis pamiatok na Slovensku uvádza prvú zmienku o kostole $\mathrm{z}$ roku 1221. Zároveň datuje prestavbu pôvodného románskeho kostola do gotického slohu s polygonálnym presbytériom do prvej polovice 14. storočia. Rebrové klenby v sakristii so svorníkmi s motívom Agnus Dei a hlavou Krista sú datované do polovice 14. storočia. V roku 1770 došlo k výstavbe oratória a v roku 1794 postavili na južnej strane kostola kaplnku rodiny Ormosdy s kryptou. V rokoch 1937-1939 bol kostol rozšírený na juh a sever prístavbami novodobých bočných lodí (SPS, 494).

Kostol bol za kultúrnu pamiatku vyhlásený už v roku 1963, ale okrem reštaurovania fresiek v sakristii v 80. rokoch 20. storočia, dlhodobo unikal pozornosti odbornej verejnosti. Pri reštaurátorskom výskume v sakristii v rokoch 1989-1990 boli odkryté fresky s motívom Legendy sv. Juraja. Cyklus je datovaný do štyridsiatych rokov 14. storočia (Smoláková 2006, 437, 439-440). Archívny výskum, ktorý predchádzal posledným výskumom (P. Buday) spresnil najmä datovanie novodobých prístavieb a prestavby kostola. Odpoved' na stavebné počiatky a stredoveký vývoj kostola priniesli až pamiatkové výskumy v rokoch 2015-2018, ktoré sa zamerali na identifikáciu jeho najstarších vývojových fáz.

\section{Archeologický výskum}

Areál kostola bol archeologicky skúmaný až od roku 2011. Počas sledovania výkopov pre inžinierske siete $\mathrm{v}$ exteriéri kostola a fary bol zachytený ohradný múr cintorína s niekol'kými prestavbami. Počas výskumu neboli odkryté hroby v primárnych polohách (Harmadyová-Divileková 2011, 10-13).

Archeologický výskum súvisiaci s obnovou kostola realizovaný Mestským ústavom ochrany pamiatok v Bratislave začal v roku 2015 a do súčasnosti prebehli tri výskumné sezóny $(2015,2016$ a 2018) (Šimončičová Koóšová 2016; 2017). Zároveň bol realizovaný architektonicko-historický 


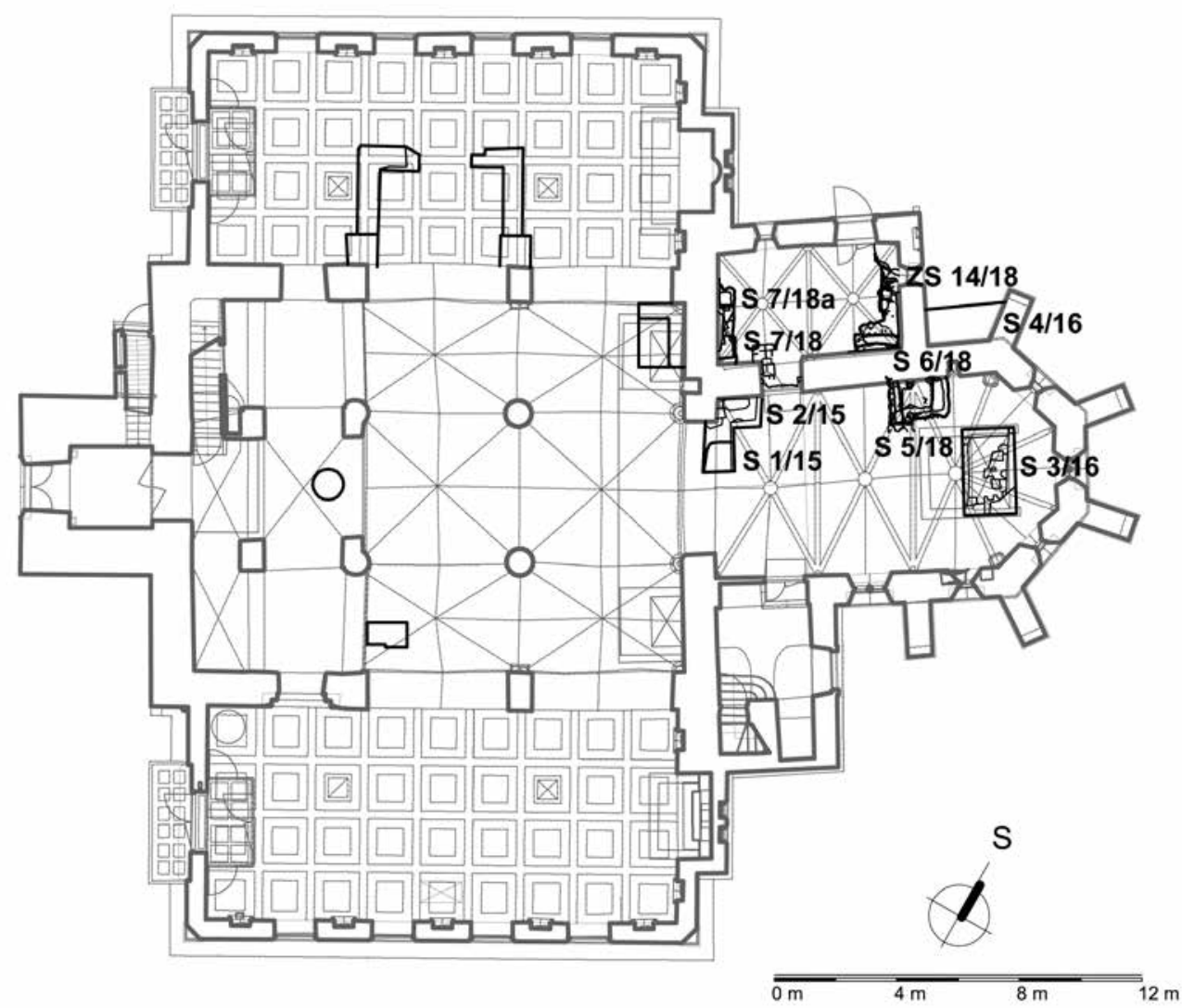

Obr. 2. Realizované sondy v Kostole sv. Mikuláša v rokoch 2015-2018. Abb. 2. In den Jahren 2015-2018 in der Nikolauskirche gelegte Sondierschnitte.

výskum (Botek-Erdélyi-Pauliny-Vachová 2015; 2016). Primárnym cielom výskumu bola identifikácia najstaršej sakrálnej stavby na mieste súčasného Kostola sv. Mikuláša. Na základe vyššie uvedených téz sme predpokladali existenciu staršej fázy presbytéria, preto práve priestor svätyne bol najviac skúmaný archeologickými sondami (obr. 2). Prvé dve (S1/15, S2/15) boli vytýčené v kontakte s triumfálnym oblúkom a vychýleným múrom sakristie. Stavebno-historický výskum predpokladal, že severozápadné murivo presbytéria mohlo do seba poňat' staršie, čo spôsobilo jeho zhrubnutie a vychýlenie v porovnaní s juhovýchodnou stenou svätyne. Ďalšia sonda (S3/16) bola otvorená po odstránení hlavného oltára v súvislosti s reštaurátorským výskumom presbytéria. V žiadnej z uvedených sond sa nám toho času nepodarilo zachytit' vertikálnu stratigrafiu, t. j. murivo, ktoré by sme mohli spojit's najstarším stavebným horizontom. Sonda S4/16 bola vytýčená v exteriéri kostola, $v$ kontakte so severozápadným murivom presbytéria, oporným pilierom a severovýchodným murivom sakristie. V roku 2018 sme v súvislosti s výmenou dlažby vytýčili sondu S5/18 v mieste anomálie zachytenej georadarovým prieskumom v roku 2017. Archeologicky bol potvrdený nález kamenného muriva (obj. 11/18), ktoré sme sledovali d’alej v priestore sakristie (sondy S5/18, ZS14/18, S7/18 a S7/18a). Výsledky výskumu z roku 2018 nám umožnili aspoň čiastočne osvetlit' najstarší vývoj stavby.

Archeologický výskum vychádzal z predpokladu, že anomália neštandardne stojaceho juhovýchodného muriva sakristie bola spôsobená zakomponovaním staršieho objektu do uvedenej 
steny. K potvrdeniu tézy došlo až v sondách S6/18 a S7/18. Išlo o mohutné základové murivo postaveného z lomového kameňa spájaného pevnou bielou vápennou maltou. Boli v ňom zamurované kosti z porušených hrobov (podobná situácia zistená aj v sonde S4/16). Tie sú podla nášho názoru dokladom, že murivo bolo postavené do existujúcej vrstvy staršieho cintorína zachyteného v S4/16. V nej bolo viditel'né, že mladšie gotické murivo stojí na staršom,t. č. interpretovanom ako románskom základe a kopíruje jeho priebeh vrátane zatočenia smerom pod oporný pilier. V sonde S5/18 nebola situácia úplne čitatel'ná. Opracované kvádre gotického (?) muriva boli položené na podlahu č. 4 , ktorá pod ne zachádzala. Zo severovýchodnej strany od obj. 11/18, pod uvedenou podlahou, základové murivo severozápadnej steny presbytéria ustupovalo smerom von. Až v híbke ca $132,33 \mathrm{~m} \mathrm{n}$. m. opät' kopírovalo líniu vyššej steny. V tejto úrovni sa zdalo, že jeden riadok zachovaného muriva možno označit' za nadzákladový a pod ním nasledovalo základové murivo. $Z$ toho usudzujeme, že obj. 11/18 narušil staršie murivo zachované vo forme rozšíreného základu.

Geofyzikálne meranie z júla 2017 zachytilo priebeh líniového muriva v presbytériu kostola. V mieste nálezu bola vytýčená overovacia sonda S5/18. V híbke ca 133,04-133,09 m n. m. sme tesne pod vrstvou podlahy č. 4 narazili na korunu líniového muriva. Označili sme ho ako objekt 11/18. V sonde S5/18 malo orientáciu severozápad-juhovýchod a jeho šírka sa pohybovala okolo $100 \mathrm{~cm}$. Jeho štruktúra bola v rámci ostatných murív skúmaných v Kostole sv. Mikuláša vel’mi špecifická. Do hrubej vrstvy sivej malty s výrazným zastúpením štrku boli osadené lomové kamene. Objekt 11/18 prerušil staršie murivo pod severozápadnou stenou presbytéria a pokračoval d’alej na severozápad. Bol viditel'ný aj v exteriérovej sonde $S 4 / 18$, v jej južnom rohu. Porušil hroby č. 3/16 a 4/16. Vo výsledkoch geofyzikálneho merania sa murivo prejavovalo výraznými reflexnými hyperbolami usporiadanými nad sebou s dobre definovaným ohraničením v híbke ca od 0,6 až do 2,0 m. Tieto anomálie pokračujú v línii smerom na juhovýchod. Vo vzdialenosti $1 \mathrm{~m}$ od severozápadnej steny presbytéria má ich prejav nižšiu intenzitu a ich vrchná čast' postupne klesá. Od ca $3 \mathrm{~m}$ od sakristie sa už anomálie nedajú identifikovat'. Uvedený predpoklad nebol overený výkopom.

Sonda S6/18 zachytila (po rozšírení formou ZS14/18) nárožie a celú šírku muriva objektu 11/18. V sakristii murivo zmenilo smer a otočilo sa rovnobežne so severozápadnou stenou presbytéria v odstupe ca $40 \mathrm{~cm}$ na juhozápad, k lodi kostola. Nárožie objektu 11/18 bolo použité ako čast' základu oporného piliera a neskôr severovýchodnej steny sakristie. V sakristii sme priebeh muriva (obj. 11/18) nesledovali v celej dížke. V sonde S7/18 (neskôr rozšírená o S7/18a) sme zachytili záver objektu 11/18, ktorý dobiehal k severovýchodnej stene severnej bočnej lode. Prepojenie uvedených murív bolo t'ažšie čitatel'né. Zdá sa, že v južnom rohu sakristie došlo k výraznejším prestavbám. Vzhl'adom na nálezovú situáciu môžeme murivo (obj. 11/18) datovat' len rámcovo. Porušilo hroby č. $3 / 16$ a 4/16t. č. existujúceho cintorína a prekryla ho podlaha č. 4 (S5/18), ktorá je pravdepodobne prvou položenou v úplnom rozsahu polygonálneho presbytéria. Jeho výstavba je datovaná do druhej polovice 13. storočia. Preto kladieme existenciu objektu $11 / 18$ do 12 . storočia.

Počas archeologického výskumu presbytéria Kostola sv. Mikuláša bola podrobne zdokumentovaná horizontálna stratigrafia stredovekých a novovekých podláh (obr. 3).

Zatial' najstarším zachyteným stavebným horizontom je podlaha č. $8( \pm 132,70 \mathrm{~m} \mathrm{n}$. m.) v sonde S3/16. Bola svetlosivá maltová s vel’mi jemnozrnnou štruktúrou. Zvrchu ju prekrývala tmavohnedá hlinitá vrstva s vysokým podielom vel'kých kostí v sekundárnych polohách, ktorú interpretujeme ako vrstvu porušeného cintorína. Ide o relikt súčasný alebo mladší ako cintorín zachytený v exteriéri, ktorý je starší ako základ zachytený pod severozápadným murivom presbytéria. Vzt'ah uvedeného muriva a podlahy č. 8 nebolo možné zatial' vyhodnotit'. Podlahu č. 8 datujeme rámcovo do 11 . storočia.

Do románskeho obdobia spadajú dlážky č. 4 a 5 v sondách S1/15 a S2/15. Boli datované pred vznik súčasného presbytéria. V sonde $\mathrm{S} 3 / 16$ možno do najstarších stavebných horizontov zaradit' nivelety označené ako podlaha č. 7 až 5 . Podlahu č. 7 ( $\pm 132,82 \mathrm{~m}$ n. m.) skôr pokladáme za pochôdznu niveletu súvisiacu s prestavbou kostola v prvej polovici 12. storočia (obj. 11/18). Zvrchu 
3a

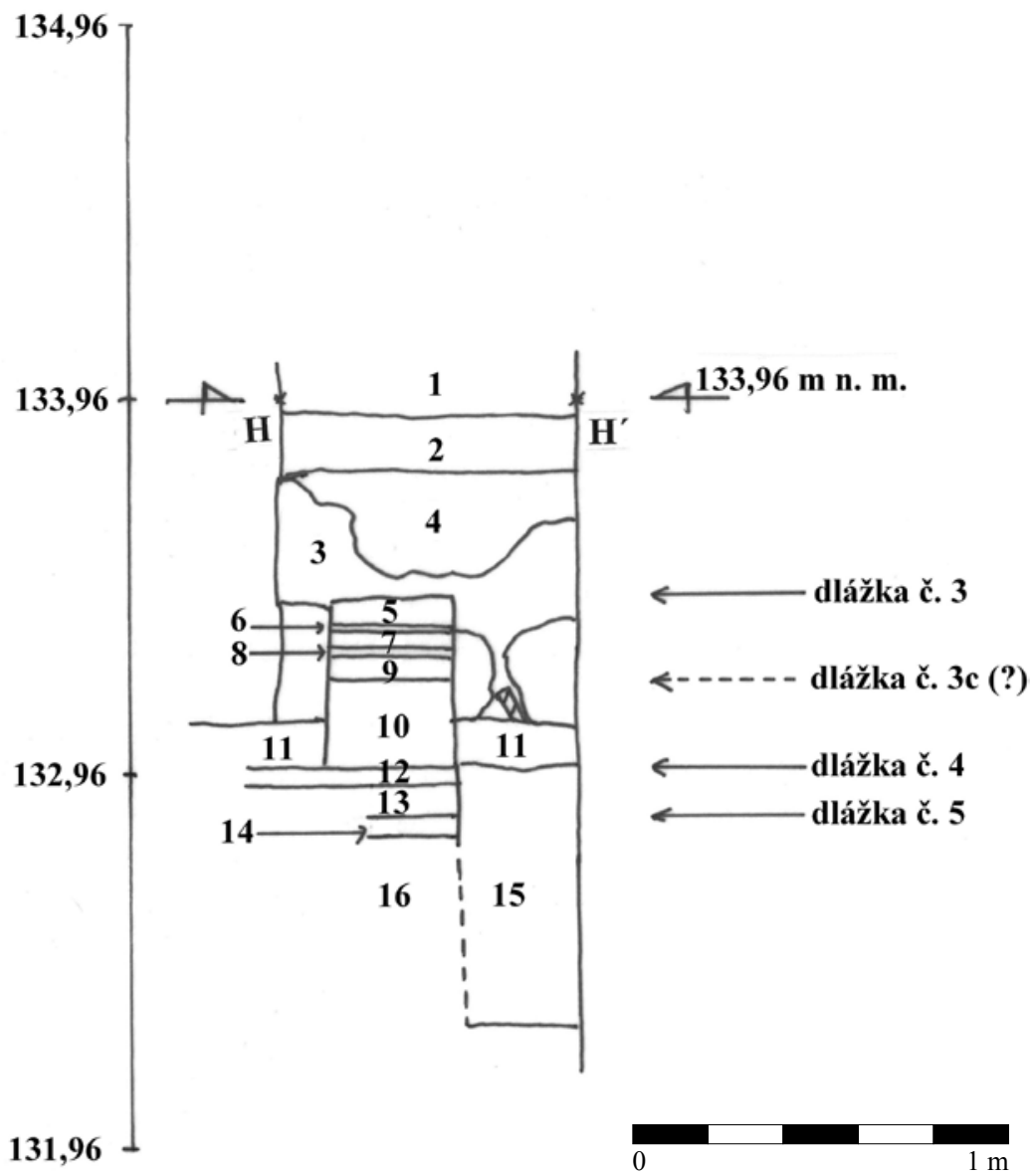

3b

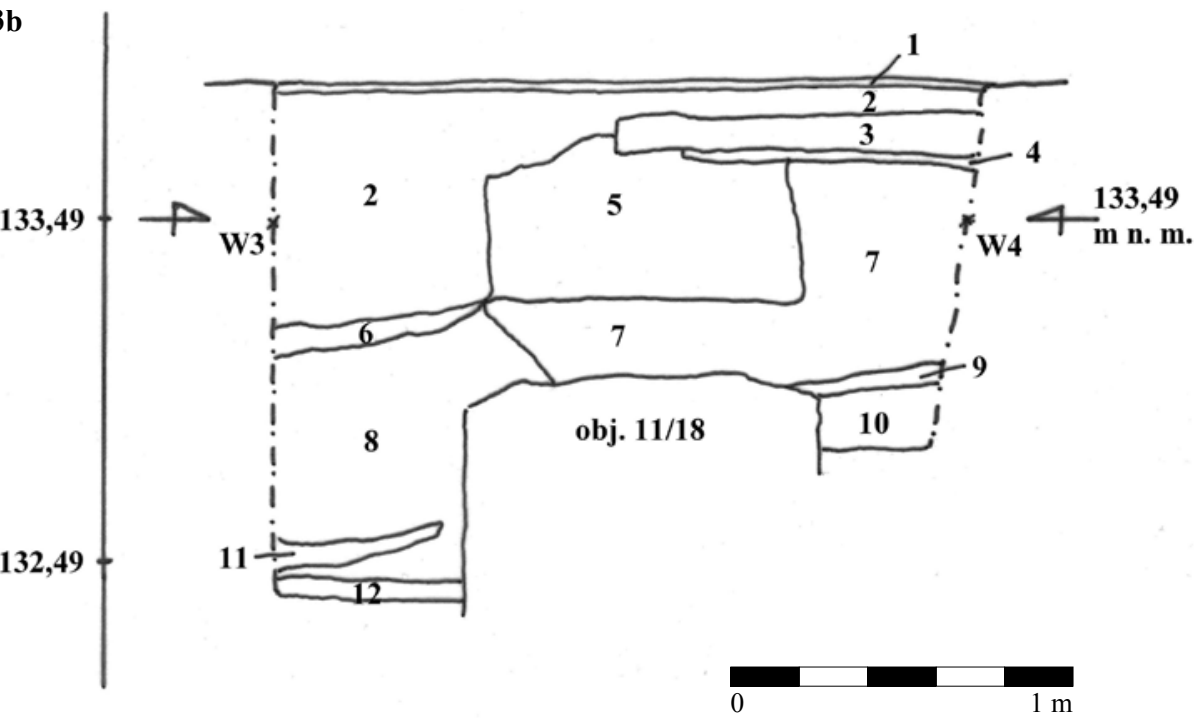


$3 \mathbf{c}$

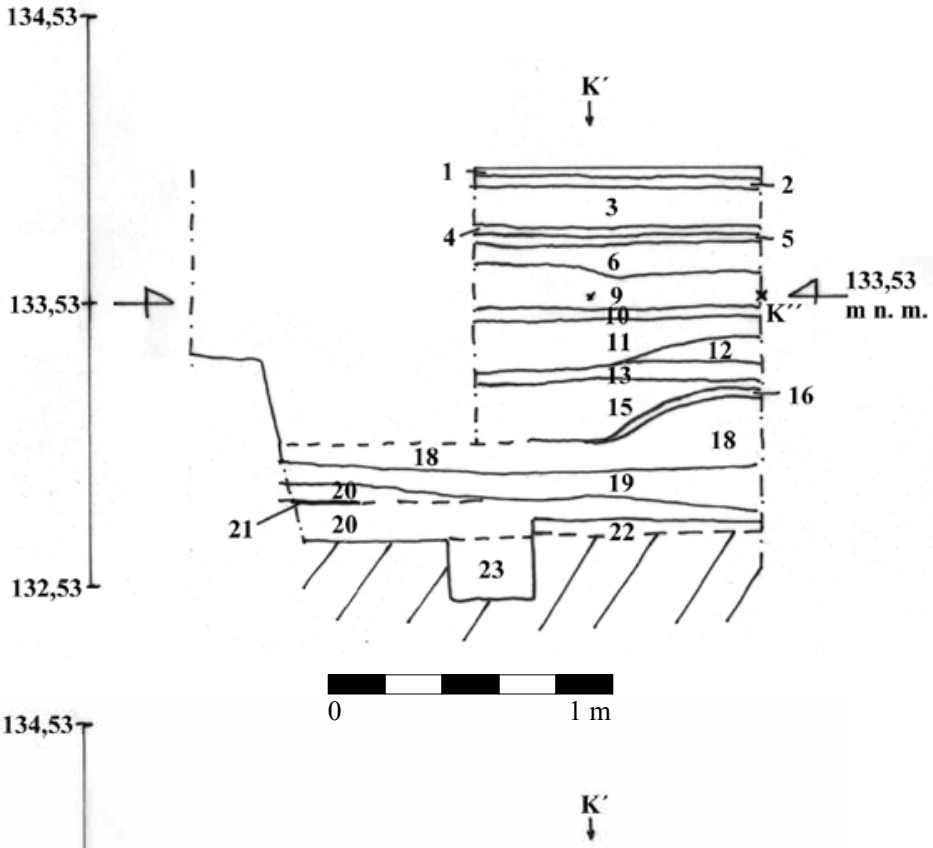

3d

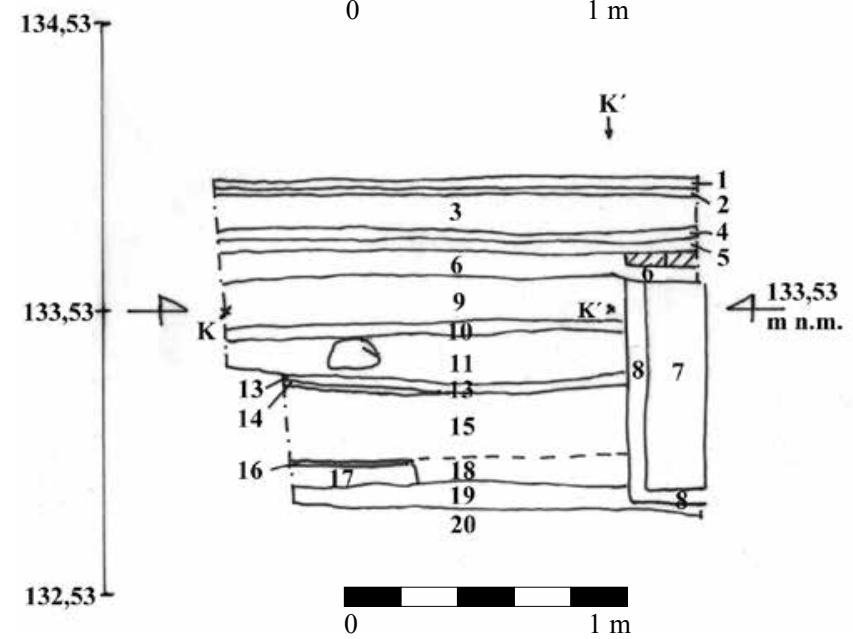

Obr. 3. Kostol sv. Mikuláša, Bratislava-Podunajské Biskupice. Profily s niveletami zachytených podláh. a - sonda S2/15, JZ profil; b - sonda S5/18, JV profil; c - sonda S3/16, SZ profil; d - sonda S3/16, SZ profil po rozš́rení v severnom rohu. Kresba P. Šimončičová Koóšová.

Legenda:

a) 1 - omietnuté murivo triumfálneho muriva; 2 - odtlačky novodobých obkladačiek; 3 - opracovaný kamenný kváder; 4 sivobiela vápenná omietka; 5 - kontrolný blok (KB), dlážka č. 3, šedá liata maltová s malými kamienkami; 6 - KB, dlážka č. 3a, šedo-hnedá liata, vápenná maltová s malými kamienkami; 7 - KB, pieskovo-kamenistá podsýpka pod dlážkou č. 3a; 8 - KB, dlážka č. 3b, svetlosivá liata vápenná maltová s malým obsahom kamienkov; 9 - KB, podsýpka pod dlážkou č. 3b; 10 - KB, homogénna hnedá hlinitá vrstva; 11 - ZS1/15, maltové lôžko triumfálneho oblúka s obsahom jemného štrku a zlomkov plevových tehál; 12 - obj. $2 / 15$ = dlážka č. 4 , sivobiela liata vápenná malta s obsahom menších kamienkov; 13 - hnedá hlinito-mazanicová vrstva; 14 - dlážka č. 5, hnedosivá maltová podlaha s vysokým podielom štrku; 15 - ZS1/15, základové murivo triumfálneho oblúka, lomový kameň spájaný bielosivou hrubozrnnou vápennou maltou; 16 - hnedá, hlinitá vrstva obsahujúca roztrúsené l'udské kosti.

b) 1 - podlaha č. 1, maltové lôžko a zvyšky opukovej dlažby; 2 - hnedožltá sut'ová pieskovo-hlinitá vrstva; 3 - hnedá hlinito-piesčitá vrstva s kamienkami; 4 - podlaha č. 2 (?), svetlosivá liata vápenná malta s kamienkami; 5 - hnedožltá hlinito-ílová vrstva s kamienkami, zlomkami malty a kostí; 6 - homogénna žltohnedá ílovo-piesková vrstva; 7 - tmavohnedá hlinitá vrstva so zlomkami malty, kostí a kameňmi; 8 - tmavohnedá hlinito-ílová vrstva so zlomkami malty, kostí a kamienkami; 9 - podlaha č. 4, sivobiela liata vápenná maltová vrstva s obsahom riečneho štrku; 10 - hnedá hlinitá vrstva s malým množstvom kameňov a kostí; 11 - biela nekompaktná vápenná maltová vrstva; 12 - vel'mi heterogénna hnedá hlinitá vrstva s výrazným podielom zlomkov malty. 
c-d) 1 - novodobá dlažba; 2 - sivá vrstva jemnozrnného betónu; 3 - svetlosivý betón s väčšími kamienkami; 4 - podsypová sivá štrkovo-piesková vrstva; 5 - podlaha č. 1, dlaždice bordovej a bielej farby; 6 - podlaha č. 2 , tehlová podlaha; 7 - obj. 7/16, kolová jama vyplnená sypkou tmavohnedou hlinou; 8 - obj. 7/16, zhutnená sivá štrkopiesková vrstva; 9 - hnedá hlinitá vrstva so zlomkami kostí a malým množstvom kamienkov; 10 - podlaha č. 3, biela vápenná maltová vrstva obsahujúca štrk; 11 - sypká sivá podsypová vrstva prachová až štrková; 12 - hnedá hlinitá vrstva s obsahom kamienkov a zlomkov tehál; 13 - podlaha č. 4, sivobéžová vápenná maltová vrstva s drobnými kamienkami; 14 - podlaha č. 4a (?), hrubozrnná svetlosivá vápenná maltová vrstva s kamienkami; 15 - tmavohnedá hlinitá vrstva obsahujúca sekundárne uložené kosti a drobné kamienky; 16 - podlaha č. 5, jemnozrnná biela vápenná malta s malým množstvom kamienkov; 17 - pevná žltá ílová vrstva $s$ antropologickým materiálom v sekundárnej polohe; 18 - tmavohnedá hlinitá vrstva obsahujúca sekundárne uložené kosti a drobné kamienky; 19 - podlaha č. 6, dusaná hnedožltá hlinitá vrstva; 20 - tmavohnedá hlinitá vrstva so sekundárne uloženými vel'kými kost’ami; 21 - podlaha č. 7, dusaná hnedá hlinitá vrstva so zlomkami kostí; 22 - podlaha č. 8, jemnozrnná bielosivá vápenná malta obsahujúca vel’mi malé množstvo drobných kamienkov; 23 - hnedá hlinito-ílová vrstva obsahujúca antropologické nálezy, fragmenty malty a kamienkov.

Abb. 3. Nikolauskirche, Bratislava-Podunajské Biskupice. Profile mit Niveletten der erfassten Fußböden. a - Sondierschnitt S2/15, SW-Profil; b-Sondierschnitt S5/18, SO-Profil; c-Sondierschnitt S3/16, NW-Profil; d - Sondierschnitt S3/16, NW-Profil nach Erweiterung in der Nordecke. Zeichnung P. Šimončičová Koóšová.

a) 1 - verputztes Mauerwerk des Triumphbogenmauerwerks; 2 - Abdrücke neuzeitlicher Fliesen; 3 - bearbeiteter Steinblock; 4 - grau-weißer Kalkputz; 5 - Kontrollblock (KB), Fußboden Nr. 3, grauer gegossener Mörtelboden mit kleinen Steinchen; 6 - KB, Fußboden Nr. 3a, grau-braun gegossener Kalkmörtelboden mit kleinen Steinchen; 7 - KB, Sandstein-Steinpacklage unter Fußboden Nr. 3a; 8 - KB, Fußboden Nr. 3b, hellgrauer gegossener Kalkmörtelboden mit geringem Gehalt an Steinchen; 9 - KB, Packlage unter Fußboden Nr. 3b; 10 - KB, homogene braune lehmhaltige Schicht; 11 ZS1/15, Mörtelbettung des Triumphbogens mit feinem Kies und Luftziegelbruchstücken; 12 - Obj. $2 / 15=$ Fußboden Nr. 4, grau-weißer gegossener Kalkmörtelboden mit kleineren Steinchen; 13 - braune Lehm-Verputzschicht; 14 - Fußboden Nr. 5, braun-grauer Boden mit hohem Kiesanteil; 15 - ZS1/15, Fundamentmauerwerk des Triumphbogens, durch weiß-grauen grobkörnigen Kalkmörtel verbundene Bruchsteine; 16 - braune Lehmschicht mit verstreuten menschlichen Knochen.

b) 1 - Fußboden Nr. 1, Mörtelbettung und Reste einer Plänerpflasterung; 2 - braun-gelbe Sandstein-Lehm-Bauschuttschicht; 3 - braune Lehm-Sand-Schicht mit Steinchen; 4 - Fußboden Nr. 2 (?), hellgrauer gegossener Kalkmörtelboden mit Steinchen; 5 - braun-gelbe Lehm-Tonschicht mit Steinchen, mit Mörtelbruchstücken und Knochen; 6 - homogene gelb-braune Ton-Sandschicht; 7 - dunkelbraune Lehmschicht mit Mörtelbruchstücken, Knochen und Steinen; 8 - dunkel-braune Lehm-Tonschicht mit Mörtelbruchstücken, Knochen und Steinchen; 9 - Fußboden Nr. 4, grau-weiße gegossene Kalkmörtelschicht mit Flusskies; 10 - braune Lehmschicht mit geringer Menge an Steinen und Knochen; 11 - weiße nicht kompakte Kalkmörtelschicht; 12 - sehr heterogene braune Lehmschicht mit deutlichem Anteil an Mörtelbruchstücken. c-d) 1 - neuzeitliche Pflasterung; 2 - graue Schicht feinkörnigen Betons; 3 - hellgrauer Beton mit größeren Steinen; 4 - graue Kies-Sand-Packlagenschicht; 5 - Fußboden Nr. 1, bordeauxrote und weiße Pflastersteine; 6 - Fußboden Nr. 2 , Ziegelfußboden; 7 - Obj. 7/16, Pfahlgrube mit lockerer dunkelbrauner Lehmverfüllung; 8 - Obj. 7/16, verdichtete graue Kies-Sandschicht; 9 - braune Lehmschicht mit Knochenfragmenten und geringer Menge an Steinchen; 10 - Fußboden Nr. 3, weiße kieshaltige Kalkmörtelschicht; 11 - lockere graue pulvrige bis schotterartige Packlagenschicht; 12 - braune Lehmschicht mit Steinchen und Ziegelbruchstücken; 13 - Fußboden Nr. 4, grau-beige Kalkmörtelschicht mit kleinen Steinchen; 14 - Fußboden Nr. 4a (?), grobkörnige hellgraue Kalkmörtelschicht mit Steinchen; 15 - dunkelbraune Lehmschicht mit sekundär deponierten Knochen und kleinen Steinchen; 16 - Fußboden Nr. 5, feinkörniger weißer Kalkmörtel mit geringer Menge an Steinchen; 17 - feste gelbe Tonschicht mit anthropologischem Material in Sekundärlage; 18 - dunkelbraune Lehmschicht mit sekundär deponierten Knochen und kleinen Steinchen; 19 - Fußboden Nr. 6, gestampfte braungelbe Lehmschicht; 20 - dunkelbraune Lehmschicht mit großen sekundär deponierten Knochen; 21 - Fußboden Nr. 7, braune gestampfte Lehmschicht mit Knochenfragmenten; 22 - Fußboden Nr. 8, feinkörniger weiß-grauer Kalkmörtel mit sehr geringer Menge an kleinen Steinchen; 23 - braune Lehm-Tonschicht mit anthropologischen Funden, Mörtelfragmenten und Steinchen.

i zospodu ju obklopovala vrstva hnedej hliny s vel'kým množstvom sekundárne uložených kostí. Udusaná, pevná ílovo-hlinitá vrstva hnedožltej farby, miestami so zachovanou tenkou maltovou vrstvičkou s drobnými kamienkami bola označená ako podlaha č. $6(132,83-133,00 \mathrm{~m}$ n.m.). Pravdepodobne v sondách S1/15 a S2/15 ju možno stotožnit's dlážkou č. $5(132,80-132,95 \mathrm{~m}$ n. m.). Z hl'adiska datovania ju spájame s 3. vývojovou fázou kostola (okolo polovice 12. storočia). Vzhl’adom na jej prevedenie však i v tomto prípade je možné uvažovat' o nej ako stavebnej nivelete súvisiacej s prestavbami v uvedenom období. Podlaha č. $5( \pm 133,05 \mathrm{~m} \mathrm{n}$. m.) v sonde $\mathrm{S} 3 / 16$ pozostávala z pomerne tenkej vrstvy bielej malty s obsahom menšieho množstva kamienkov. Na východnom okraji sondy S3/16 sa výrazne zdvíhala (133,24 m n.m.). Domnievame sa, že pokračuje až k murivu súčasného presbytéria. Jej datovanie kladieme do 13. storočia (?), t. j. do 5. vývojovej fázy kostola. V sondách $\mathrm{S} 1 / 15$ a S2/15 by sme ju mohli stotožnit's dlážkou č. 4 (132,96-133,10 m n. m.). Podl'a všetkého je prvou podlahovou úpravou, ktorá scelila priestor v súčasnosti existujúceho presbytéria a prekryla objekt 11/18.

V sonde S5/18 sa pod vrstvou tvrdej ílovej žltej až hnedej hliny s minimálnym obsahom kamienkov a s väčším množstvom antropologických nálezov v sekundárnych polohách objavila takmer na celej ploche liata vápenná maltová vrstva sivohnedej farby obsahujúca riečny štrk. 
Označili sme ju ako podlaha č. 4 (133,16 m n.m). Jej povrch nebol rovný, ale výrazne poškodený, zvlnený. Predpokladáme, že ide o mladšiu románsku podlahu zachytenú v sondách S1-S2/15 (dlážka č. 4), ako aj v S3/16 (podlaha č. 5 ?).

Zdá sa, že medzníkom medzi najstaršími podlahami zistenými v blízkosti triumfálneho oblúka (S1/15, S2/15) a situáciou pod hlavným oltárom (S3/16) je objekt 11/18. Kým v sondách S1S2/15 niveleta dlážky č. 5 mala povrch jednoznačne úmyselne upravený, vrstvu označenú ako podlaha č. 6 v sonde S3/16 už nemožno takto interpretovat'. V sonde S5/18 nedosadala priamo k objektu 11/18 žiadna z uvedených niveliet. Zo severovýchodnej strany muriva (ZS11/18) sme zachytili približne v úrovni podlahy č. 8 (S4/16) výrazne zničenú maltovú vrstvu. Domnievame sa, že murivo obj. 11/18 podlahu zničilo.

Pozdĺž severozápadného muriva presbytéria prekrývala podlahu č. 4 v sonde S5/18 sypká biela maltová vrstva s výrazným podielom riečneho štrku, ktorá sa nachádzala pod úrovňou opracovaných neomietnutých kamenných kvádrov gotického muriva. Predpokladáme, že išlo o stavebnú niveletu súvisiacu $\mathrm{s}$ výstavbou presbytéria $\mathrm{v}$ súčasnom tvare a rozsahu, podobne ako v S4/16 podlahu č. 9 a v S6/18-ZS14/18 maltovú vrstvu prekrývajúcu čast' obj. 11/18 pozdíž severovýchodnej steny sakristie.

V sakristii sa vo viacerých sondách objavila udusaná vrstva hnedej hliny. V sonde S6/18 prekrývala rozšírený základ juhovýchodnej steny $(133,24-133,29 \mathrm{~m}$ n.m.). Pravdepodobne ide o pochôdznu úroveň pred výstavbou sakristie. Podobnú situáciu sme zachytili v S7/18a (ca $133,18 \mathrm{~m} \mathrm{n.m)}$. V tomto priestore (S7/18a) bola pod ňou v malom rozsahu odkrytá aj najnižšia maltová vrstva $( \pm 133,02-133,04 \mathrm{~m}$ n. m.), ktorá mohla byt' podlahou (?) bližšie neidentifikovaného priestoru.

Priestor cintorína sa nám podarilo skúmat' len v exteriéri kostola (obr. 4). Celkovo bolo zachytených sedem hrobov. Situácia v sonde S4/16 nebola vhodná na vytvorenie detailnejšej chronológie horizontov pochovávania, ktoré by korelovali so stavebným vývojom kostola. Boli sme schopní odčlenit' najstarší horizont hrobov, ktoré boli pravdepodobne vyhĺbené v blízkosti najstaršej sakrálnej (?) stavby na sledovanom území,t. j. v období od prelomu 10. až 11. storočia do 12. storočia. Horizont datujeme na základe nálezu esovitej záušnice (Pr. č. 271/16). Vrstva najstaršieho cintorína je zvrchu uzavretá exteriérovou niveletou označenou ako podlaha č. 9 . Ide o pomerne hrubú bielu vápennú maltovú vrstvu s nehladeným povrchom. Pokladáme ju za pozostatok stavebnej činnosti súvisiacej s prestavbou presbytéria. Našli sa v nej zlomky malovanej omietky. Mohla vzniknút' v období existencie alebo pri búraní stavby spájanej s rozšíreným základom pod severozápadnou stenou presbytéria alebo pri výstavbe gotickej svätyne. Niveleta je tesne pod úrovňou koruny strhnutého základového muriva, preto je t’ažké jednoznačne ju priradit' k stavebným úpravám po polovici 13. storočia (4. vývojová etapa). Predbežne ju datujeme na prelom 12. a 13. storočia.

Do najstaršieho horizontu pochovávania zarad'ujeme hroby č. 2/16, 2a/16, 3/16, 4/16, 5/16 a 6/16 (obr. 4). V žiadnom $\mathrm{z}$ nich sa nenašli hrobové prílohy, čiže ich príslušnost' $\mathrm{k}$ uvedenému horizontu je postavená na základe homogénnosti cintorínovej vrstvy. Išlo o výraznú tmavohnedú ílovú vrstvu obsahujúcu väčšie zlomky kostí z cintorína, do ktorej boli hroby zahíbené.

Nález esovitej záušnice (Pr. č. 271/16, obr. 5b) v tesnej blízkosti hrobu č. 2/16 zarad’uje uvedený horizont hrobov do okruhu belobrdskej kultúry. Záušnica je hladká, ukončená roztepaným dvojitým vinutím. Jej rozmery dosahujú $2,4 \times 2,0 \mathrm{~cm}$, dížka hladkej slučky je $0,7 \mathrm{~cm}$ a jej šírka $0,3 \mathrm{~cm}$. Bola vyrobená $\mathrm{z}$ bronzovej tyčinky s kruhovým prierezom $(\varnothing 0,1 \mathrm{~cm})$. Vychádzajúc z analýzy nálezov z pohrebiska v lokalite Nitra-Šindolka by sme ju zaradili do horizontu 3, typ 16. Pre ne je charakteristický priemer záušnice väčší ako $20 \mathrm{~mm}$ a hrúbka drôtu do $2 \mathrm{~mm}$. Na základe nálezov mincí prvých Arpádovcov je typ 16 datovaný do obdobia okolo polovice 11. storočia (Fusek 2012, 99-100). Rozmerovo a tvarovo vel'mi podobné nálezy esovitých záušníc pochádzajú z pohrebiska v Hurbanove-Bohatej, ktoré je datované do druhej polovice 10. až 11. storočia. Väčšina z nich bola na rozdiel od biskupického exempláru vyhotovená zo striebra. V hrobe č. 96 sa našla okrem striebornej esovitej záušnice aj minca, strieborná uhorská razba Ondreja I. (1046-1061) (Rejholcová 1976, 199-200, 225). Záušnica (Pr. č. 271/16) z Podunajských Biskupíc 
$4 a$
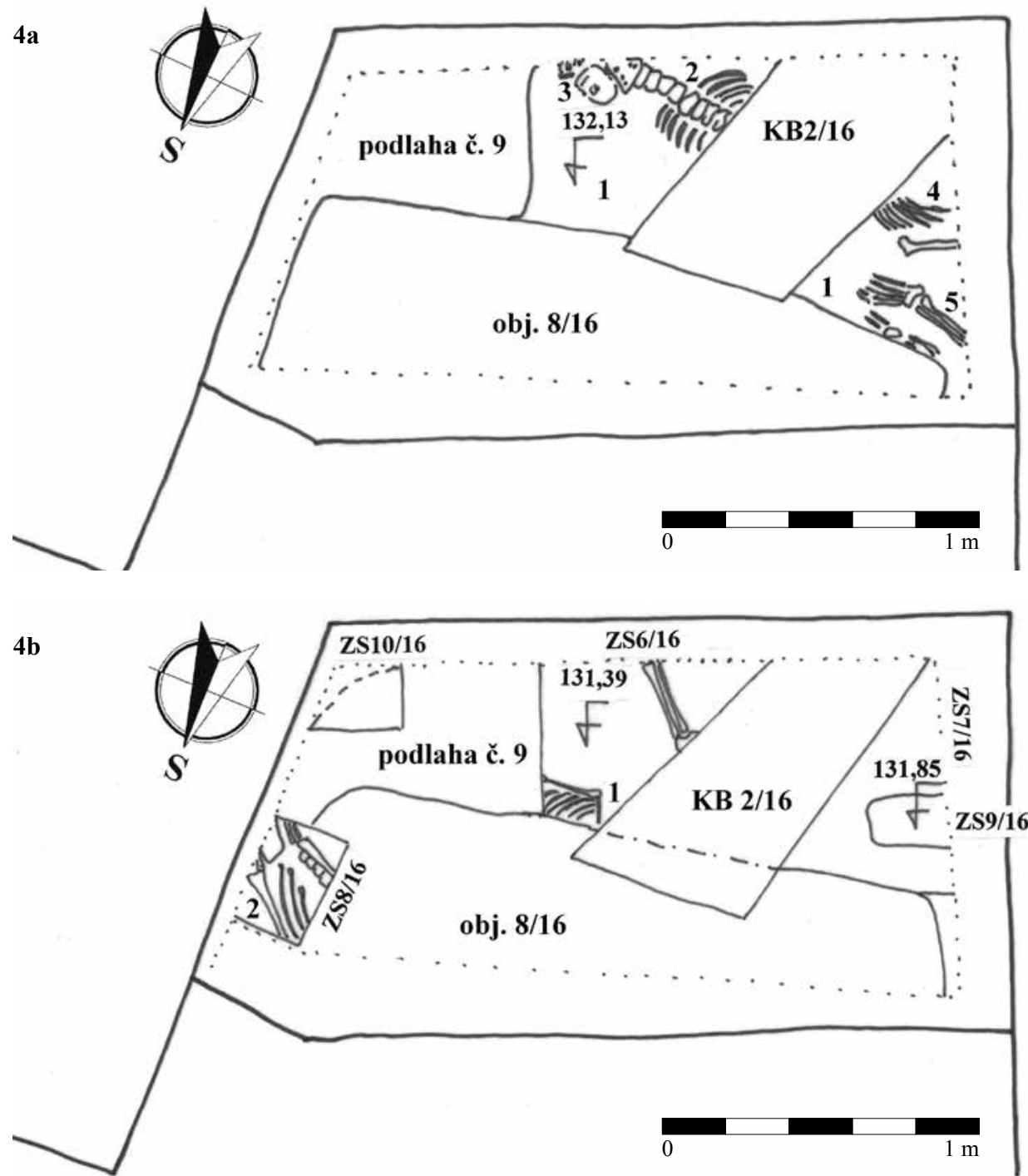

Obr. 4. Kostol sv. Mikuláša, Bratislava-Podunajské Biskupice. Hroby odkryté v exteriérovej sonde S4/16. a) hroby 2/16, 2a/16, 3/16, 4/16; b) hroby 5/16, 6/16. Kresba P. Šimončičová Koóšová.

Legenda:

a) 1 - homogénna antropogénna tmavohnedá ílová vrstva s vysokým podielom vel’kých sekundárne uložených kostrových pozostatkov (vrstva cintorína); 2 - hrob č. 2/16, 132,15 m n. m.; 3 - hrob č. 2a/16, 132,145 m n. m.; 4 - hrob č. 3/16, $132,14 \mathrm{~m}$ n. m.; 5 - hrob č. 4/16, 132,14 m n.m.

b) 1 - hrob č. 5/16, 132,005 m n.m.; 2 - hrob č. 6/16, 131,67 m n.m.

Abb. 4. Nikolauskirche, Bratislava-Podunajské Biskupice. Freigelegte Gräber in Außensondierschnitt S4/16. a) Gräber 2/16, 2a/16, 3/16, 4/16; b) Gräber 5/16, 6/16. Zeichnung P. Šimončičová Koóšová.

Legende:

a) 1 - homogene anthropogene dunkelbraune Tonschicht mit hohem Anteil an großen sekundär deponierten Skelettüberresten (Friedhofsschicht); 2 - Grab Nr. 2/16, 132,15 m ü. d. M.; 3 - Grab Nr. 2a/16, 132,145 m ü. d. M.; 4 - Grab Nr. 3/16, 132,14 m ü. d. M.; 5 - Grab Nr. 4/16, 132,14 m ü. d. M.

b) 1 - Grab Nr. 5/16, 132,005 m ü. d. M.; 2 - Grab Nr. 6/16, 131,67 m ü. d. M. 

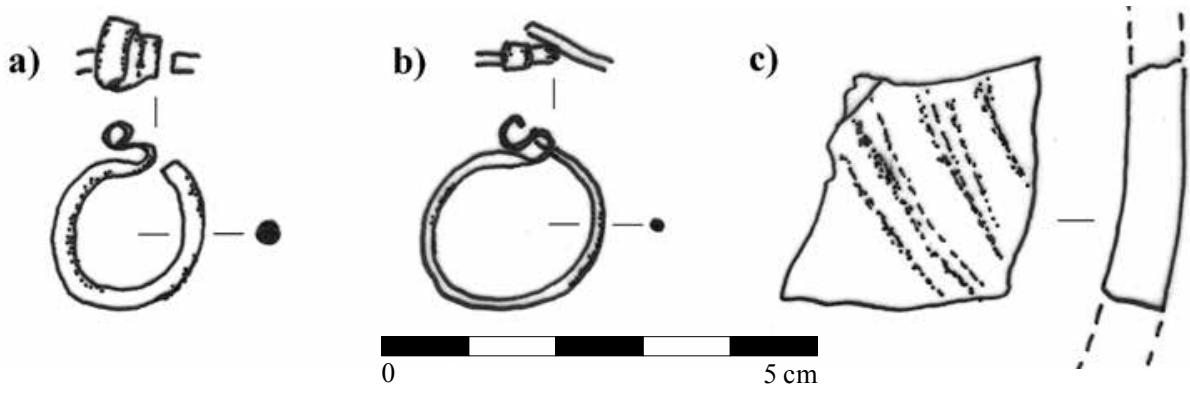

Obr. 5. Kostol sv. Mikuláša, Bratislava-Podunajské Biskupice. a - esovitá záušnica (Pr. č. 27/15), b - esovitá záušnica (Pr. č. 271/16), c - keramika (Pr. č. 6/15). Kresba P. Šimončičová Koóšová.

Abb. 5. Nikolauskirche, Bratislava-Podunajské Biskupice. a - s-förmiger Schläfenring (Zuwachsnummer 27/15), b - s-förmiger Schläfenring (Zuwachsnummer 271/16), c - Keramik (Zuwachsnummer 6/15). Zeichnung P. Šimončičová Koóšová.

sa našla tesne nad hrobom dospelého muža (hrob č. 2/16). Je možné, že nepatrila k tomuto hrobu, nakol'ko hroby boli nad sebou a navzájom sa prekrývali. Druhou možnost’ou je interpretácia záušnice ako milodaru v mužskom hrobe, kde nebola funkčným šperkom. Z analýzy pohrebiska v Čakajovciach datovaného do 9.-12. storočia vyplynulo, že záušnice sa vyskytovali najčastejšie v hroboch žien a detí a iba minimálne v hroboch mužov či jedincov vo veku juvenis (Rejholcová 1995, 27, 57).

Chronologicky dôležité nálezy z roku 2015 pochádzajú zo sekundárnych polôh, preto nie je možné nimi datovat’ odkryté situácie. Zo zásypu obj. 3/15 pochádza bronzová esovitá záušnica (Pr. č. 27/15). Išlo o novodobý zásah v sonde S1/15, ktorý narušil dlážky č. 3 až 5. Pri dne výkopu $(131,80 \mathrm{~m} \mathrm{n} . \mathrm{m}$.) sa nachádzali kostrové pozostatky v sekundárnej polohe. Zásyp bol heterogénny hlinitý, obsahujúci stavebný materiál, antropologické nálezy v sekundárnych polohách, malé množstvo keramiky a železných klincov. Esovitá záušnica (Pr. č. 27/15, obr. 5a) má široko roztepanú dvojitú slučku a jej priemer sa pohybuje okolo $1,8 \mathrm{~cm}$. Priemer drôtu je $0,2 \mathrm{~cm}$ a šírka roztepanej slučky dosahuje $0,5-0,7 \mathrm{~cm}$. Na kostrovom pohrebisku z 9.-12. storočia v Čakajovciach (okr. Nitra) sa medzi milodarmi dávanými v 11. storočí do hrobov vyskytovali vo vel'kej miere esovité záušnice. V období 10.-11. storočia boli najpočetnejším nálezom. Našli sa vo viacerých variantoch $-\mathrm{z}$ tenšieho strieborného alebo bronzového drôtu, masívnejšie zo striebornej tyčinky, hladké alebo s pozdĺžne rebrovanou esovitou slučkou. V záverečnom úseku pochovávania na uvedenom pohrebisku, v horizonte $C$ (polovica 10. až prelom 10. a 11. storočia) sa objavila esovitá záušnica so široko roztepanou slučkou (staršia fáza belobrdskej kultúry). Tento typ šperku pretrvával aj v horizonte pochovávania D (10./11. storočie až 1. desat'ročie 12. storočia), t. j. v mladšej fáze belobrdskej kultúry (Rejholcová 1975, 88; 1995, 6-7, 57; Hanuliak-Rejholcová 1999, 11). Záušnicu z Podunajských Biskupíc možno zaradit' k typu na obr. 47:32 z Čakajoviec (Hanuliak-Rejholcová 1999, 58-59). Najbližšími analógiami sú nálezy z hrobov č. 68, 264, 379, 649 a 720. Pre tzv. nitriansky typ je charakteristická roztepaná slučka so šírkou 0,7-1,2 cm (Rejholcová 1995, 57, 88), čo zodpovedá aj nálezu z Kostola sv. Mikuláša. Ďalšie analógie pochádzajú z pohrebiska v lokalite Nitra-Zobor, kde tvorili najpočetnejšiu skupinu. Na území Slovenska sa začali vyskytovat' od druhej polovice 10. storočia a pretrvali do začiatku 11. storočia (Čaplovič 1954, 28, 30). Analógia v striebornom prevedení sa našla v Hurbanove-Bohatej, v hrobe 126 spolu s mincou Ondreja I. (1046-1061; Rejholcová 1976, 202, 212). Vel'kost'ou podobné esovité záušnice s roztepanou slučkou pochádzajú z pohrebiska v Nových Zámkoch, tak v striebornom (hrob č. 8 a 29), ako i bronzovom prevedení (hrob č. 33 a 37). Pochovávalo sa tam od prelomu 10. a 11. do začiatku 12. storočia a sledované nálezy patrili k najčastejším šperkom (Rejholcová 1974, 436, 438, 443, 449).

Chronológiu pohrebísk 10.-11. storočia vytvoril G. Fusek na základe výskumu pohrebiska v lokalite Nitra-Šindolka (Fusek 2012a). Podla uvedených vlastností možno záušnicu 


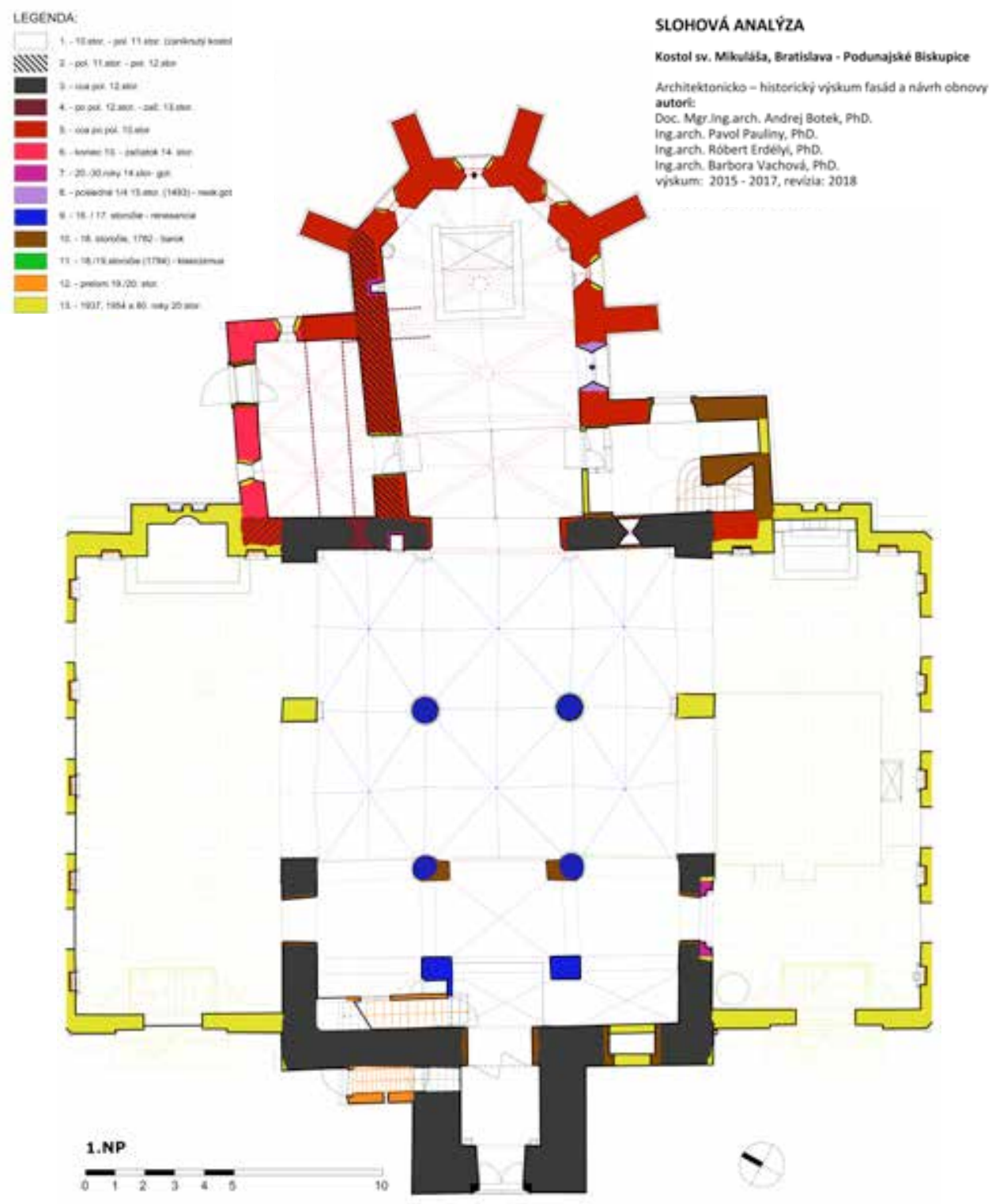

Obr. 6. Kostol sv. Mikuláša, Bratislava-Podunajské Biskupice. Stavebno-historická analýza. Abb. 6. Nikolauskirche, Bratislava-Podunajské Biskupice. Bauhistorische Analyse.

z Podunajských Biskupíc zaradit' ku Fusekovmu typu 11, spadajúcemu do staršieho stupňa belobrdskej kultúry, do 2. horizontu. Uvedený typ dosahoval priemer do $20 \mathrm{~mm} \mathrm{~s}$ hrúbkou drôtu do $3 \mathrm{~mm}$ a šírkou roztepanej slučky minimálne 7,5 mm (Fusek 2012a, 99, 110, Abb. 13). V inej publikovanej chronológii spomínaného autora ju radíme do typu $\mathrm{B}$, pre ktorý je charakteristická hrúbka drôtu do $0,3 \mathrm{~cm}$ a šírka slučky do $0,75 \mathrm{~cm}$ (Fusek 2012b, 808). Na základe vyššie uvedených analógií môžeme esovitú záušnicu (Pr. č. 27/15) z Podunajských Biskupíc datovat' na prelom 10. a 11. storočia, eventuálne do prvej polovice 11. storočia. 
Zo zásypu obj. 3/15 alebo z vrstvy zeminy deponovanej medzi dlážkami č. 2 a 3 pochádza aj zlomok tuhovej keramiky datovaný do 11.-12. storočia (Pr. č. 6/15, obr. 5c).

\section{Stavebno-historická analýza (obr. 6)}

Prvá vývojová etapa kostola (10.-11. storočie) sa predpokladá na základe ojedinelých (podlaha č. 8) a sekundárnych nálezov (zamurované fragmenty muriva s omietkou v severnej a severovýchodnej stene gotického presbytéria). Predpokladáme, že išlo o objekt - najstaršiu sakrálnu stavbu súvisiacu s prvým horizontom pochovávania pri kostole. Pravdepodobne v 11. storočí bol v superpozícii dnešného presbytéria postavený kostol, ktorého základové murivo odhalil archeologický výskum v severozápadnej stene dnešného presbytéria. Jeho orientácia bola oproti dnešnému presbytériu mierne vychýlená na severnú stranu, o čom svedčí nerovnobežný priebeh muriva medzi sakristiou a svätyňou. Pri hl'adaní analógie, rozmerov a dispozície prvého kostola sme vychádzali z nálezu sakrálnej architektúry v ned’alekom Šamoríne, datovanej rámcovo do 11. storočia. Tá mala pravouhlú lod' a polkruhovú apsidu. V polovici 12. storočia už kapacita prvého kostola nepostačovala. Západné priečelie preto zbúrali a pristavali k nemu rozsiahle románske halové trojlodie a dve podlažia predstavanej veže na osi lode kostola, čím starší kostol prevzal funkciu svätyne. Datovanie je založené na dendrochronologických dátach získaných z viacerých vzoriek $\mathrm{z}$ veže, lode i triumfálneho oblúka a použití plevových tehál s rozmerom $17 \times$ $31 \times 4 \mathrm{~cm}$ (podl'a P. Nagya boli obdobné tehly použité na Nitrianskom hrade, kde sú datované do 12. storočia). Štvrtá vývojová etapa (polovica 12. až začiatok 13. storočí) predpokladá na základe zamurovaného románskeho okna severnej lode vybudovanie staršej sakristie na mieste súčasnej. Na základe viacerých indícií výskumu a následných archeologických nálezov neznámeho muriva (objekt 11/18) v sakristii a presbytériu možno pracovat' aj s hypotézou, že kostol z druhej etapy bol po postavení nového trojlodia zbúraný a nahradený novým kvadratickým záverom kostola. V druhej polovici 13. storočia (5. vývojová etapa) bolo staršie presbytérium asanované a k románskej lodi pristavili polygonálne presbytérium so soklom a opornými piliermi. Pri jeho stavbe sa sekundárne používal kameň i plevové tehly. Na prelome 13. a 14. storočia (6. vývojová fáza) prestavali sakristiu do súčasnej podoby. V siedmej vývojovej fáze (20.-30. roky 14. storočia) zaklenuli presbytérium, gotizovali lod' kostola a nadstavili vežu. V presbytériu bol postavený nový oltár (obj. 6/16) a celý priestor svätyne bol vymal'ovaný druhou vrstvou fresiek. $\mathrm{Na}$ záver 15. storočia (8. vývojová etapa) sú datované úpravy v celom interiéri kostola - nový krov nad lod’ou a presbytériom, tretia vrstva freskovej výmal'by presbytéria. Deviata vývojová fáza kostola spadá na prelom 16. a 17. storočia. Po zrútení klenby nasledovali stavebné úpravy doplnené o nové omietky s vápennými nátermi (renesančné úpravy). K d’alšej výmal'be presbytéria mohlo dôjst' aj v druhej polovici 17. storočia. Desiata vývojová etapa zahŕňa barokové úpravy a prístavbu oratória $\mathrm{v}$ závere 18. storočia. Jedenástou stavebnou etapou bola výstavba kaplnka rodiny Ormosdy na prelome 18. a 19. storočia (klasicistické úpravy). V dvanástej vývojovej etape prebehli neogotické úpravy kostola a presbytéria vrátane osadenia súčasného Oltára sv. Mikuláša na prelome 19. a 20. storočia. Záverečná, trinásta etapa vývoja, zodpovedá úpravám v priebehu 20. storočia (v rokoch 1937, 1954, 80-te roky 20. storočia).

Autori architektonického výskumu ukončeného v roku 2016 (Botek-Erdélyi-Pauliny-Vachová 2016, 228-237; 2018) korigovali počet vývojových fáz a doplnili pred pôvodnú prvú fázu kostola ešte jednu etapu na základe výsledkov archeologického výskumu v roku 2018.

\section{Petrografické vyhodnotenie vzoriek kameňa z kostola v Podunajských Biskupiciach}

\section{Metodika}

Bolo odobraných 70 vzoriek kameňa z kamenárskych výrobkov stredovekého kostola. Vzorky boli skúmané a opísané na základe makroskopického pozorovania, s pomocou lupy zväčšujúcej 30× a digitálneho mikroskopu DigMicro Scale zväčšujúcim od 20 do 230×. Z ôsmich 
vápencov boli urobené výbrusy na pozorovanie v optickom mikroskope Carl Zeiss Jena zväčšujúcom 50×, 100× a 200×. Na základe petrografie boli dané horniny použité v kostole zaradené do geologickej jednotky, v ktorej pravdepodobne vznikali. Následne boli vytypované pravdepodobné zdroje materiálu pre výrobu kamenných výrobkov.

\section{Petrografia a proveniencia hornín}

V Kostole sv. Mikuláša bolo identifikovaných mnoho druhov hornín. Môžeme ich rozdelit' na neopracované, čo je bud' lomový kameň, alebo riečne obliaky, a opracované neogénne vápence a pieskovce.

Z neopracovaných bolo najviac granitoidných hornín (žúl), čo sú petrograficky dvojsl’udný granit až granodiorit, biotitický granit až granodiorit, pegmatit, mylonitizovaný granit až granodiorit s chloritom. Spomínané horniny spolu s ojedinelými amfibolitom a pararulou patria do kryštalického jadra Malých Karpát neskoro prvohorného veku (Vysvetlivky 2012), ktoré vystupujú na povrch od Devína cez Bratislavu až po Pezinok. Nájdený bol aj kremenec, ktorý môže pochádzat' z oblasti Devína.

Opracované horniny môžeme rozdelit' na riasové vápence, organogénne vápence, lumachelové vápence, hybridné pieskovce a kremenné pieskovce.

\section{Pórovité riasové vápence (obr. $7 \mathrm{a}, \mathrm{b})$}

Riasové silne pórovité vápence krémovo-sivej farby sú hrubozrnnej $(0,5-1 \mathrm{~mm})$ až strednozrnnej $(0,35-0,5 \mathrm{~mm})$, zriedkavejšie jemnozrnnej vel'kosti $(0,1-0,35 \mathrm{~mm})$. V hrubozrnnejších typoch môžu byt' rozptýlené úlomky až niekol'ko milimetrov vel'ké. Makroskopicky majú vápence lamináciu - u hrubozrnnejších striedanie vrstvičiek s rôznou zrnitostou a u jemných menej spevnené a viac spevnené (tmelené) vrstvičky.

Vápence sú zvyčajne dobre triedené, zložené najmä z úlomkov fosílií (40-70\%) a premenlivého množstva kremeňa, kremenných hornín a slúd (1-30\%). Z fosílií prevládajú oválne až ostrohranné riasové hlúzky (30-60\%). Prítomné sú aj úlomky lastúrnikov, ježoviek, dierkavcov, rúrok červov a lastúrničky. Zrná sú spojené jemným obalovým, lokálne blokovým kalcitovým tmelom (15-30\%). Podiel pórov tvorí 10-15\%.

Tento typ riasového vápenca je najpodobnejší na riasové vápence bádenského veku zo severu Litavských vrchov medzi Kaisersteinbruchom, Bruckom an der Leitha, Parndorfom a Windenom am See. Niektoré viac spevnené vápence s vel'kými foraminiferami sú príbuzné lokalite Kaisersteinbruch. Na jemnozrnné až strednozrnné typy je podobný litavský vápenec zo St. Margarethenu. Tiež má prevahu rias nad inými fosíliami a jemný obalový tmel. U vápencov zo severu Litavských vrchov je pomer rias ku všetkým fosíliám 56-86\%, u vápencov zo St. Margarethenu 40-78 \%. Okrem rias u prvých dominujú ježovky nad hyalinnymi foraminiferami (vtedy je vysoký obsah siliciklastických hornín 7-42\%), či prevládajú lastúrniky, alebo sú prítomné vel'ké foraminifery. U druhých dominujú hyalinné foraminifery nad ježovkami, alebo opačne, niekedy je vel’a porcelánových dierkavcov, viac lastúrnikov či machoviek. U prvých je obsah siliciklastov ku všetkým úlomkom $0-6 \%$, väčšinou do $1 \%$, u druhých od ca 1-39\%. Zloženie siliciklastických úlomkov je podobné.

Riasové vápence (obr. 7c, d)

Žltkastobiele až sivobiele riasové vápence sú tvorené najmä riasovými hlúzkami s vel'kost'ou do niekol'kých milimetrov. Z d'alších súčastí sú prítomné úlomky lastúrnikov, ježoviek, machoviek, rúrky červov a schránky dierkavcov. Podradne zastúpená klastická prímes (do $2 \%$ ) je reprezentovaná svetlosivými a hnedými zrnkami kremeňa a sivými, prípadne ružovými karbonátmi. Medzi hl'úzkami je základná hmota a kalcitový tmel, pórovitost' je nízka. Podobné horniny bádenského veku sa nachádzajú v kameňolomoch v Hainburských vrchoch medzi Hainburgom a Hudsheimom. Určitú príbuznost' majú aj s vápencami pri Devíne. 

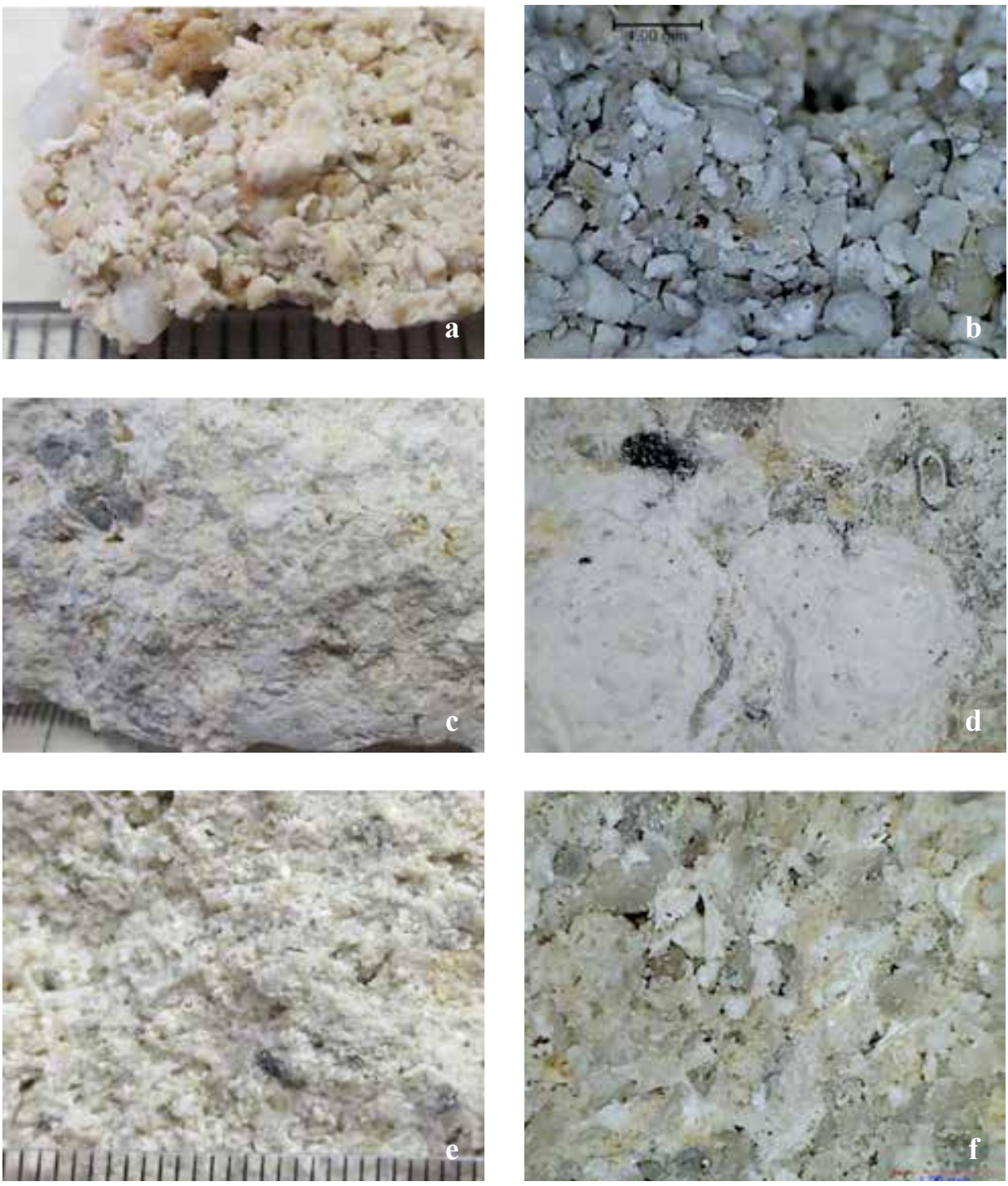

Obr. 7. Makroskopické a mikroskopické snímky kameňov Kostola sv. Mikuláša. a-b - pórovitý riasový vápenec; c-d - riasový vápenec; e-f - organogénny vápenec. Foto D. Pivko.

Abb. 7. Makroskopische und mikroskopische Aufnahmen von Steinen der Nikolauskirche. a-b - poröser Algenkalkstein; c-d-Algenkalkstein; e-f-organogener Kalkstein. Foto D. Pivko.

Organogénne vápence (obr. 7e, f)

Krémovo-sivé organogénne vápence sú hrubozrnné až jemnozrnné. Tvorené sú riasovými hlúzkami, úlomkami ježoviek, lastúrnikov, dierkavcami a machovkami. Klastická prímes je väčšinou málo zastúpená (do $3 \%$ ) s obsahom sivých a ružových karbonátov, kremeňa a slúd. Existujú aj typy s vyšším obsahom karbonátov až do $20 \%$ a minimálnym množstvom kremeňa. Medzi zrnami sa nachádzajú póry, kalcitový tmel a často základná hmota. Najpravdepodobnejšou lokalitou tohto typu organogénnych vápencov bádenského veku je čast' Hainburských vrchov medzi Hainburgom a Hundsheimom. Je tu aj určitá podobnost' na vápence z plošiny Metzen 

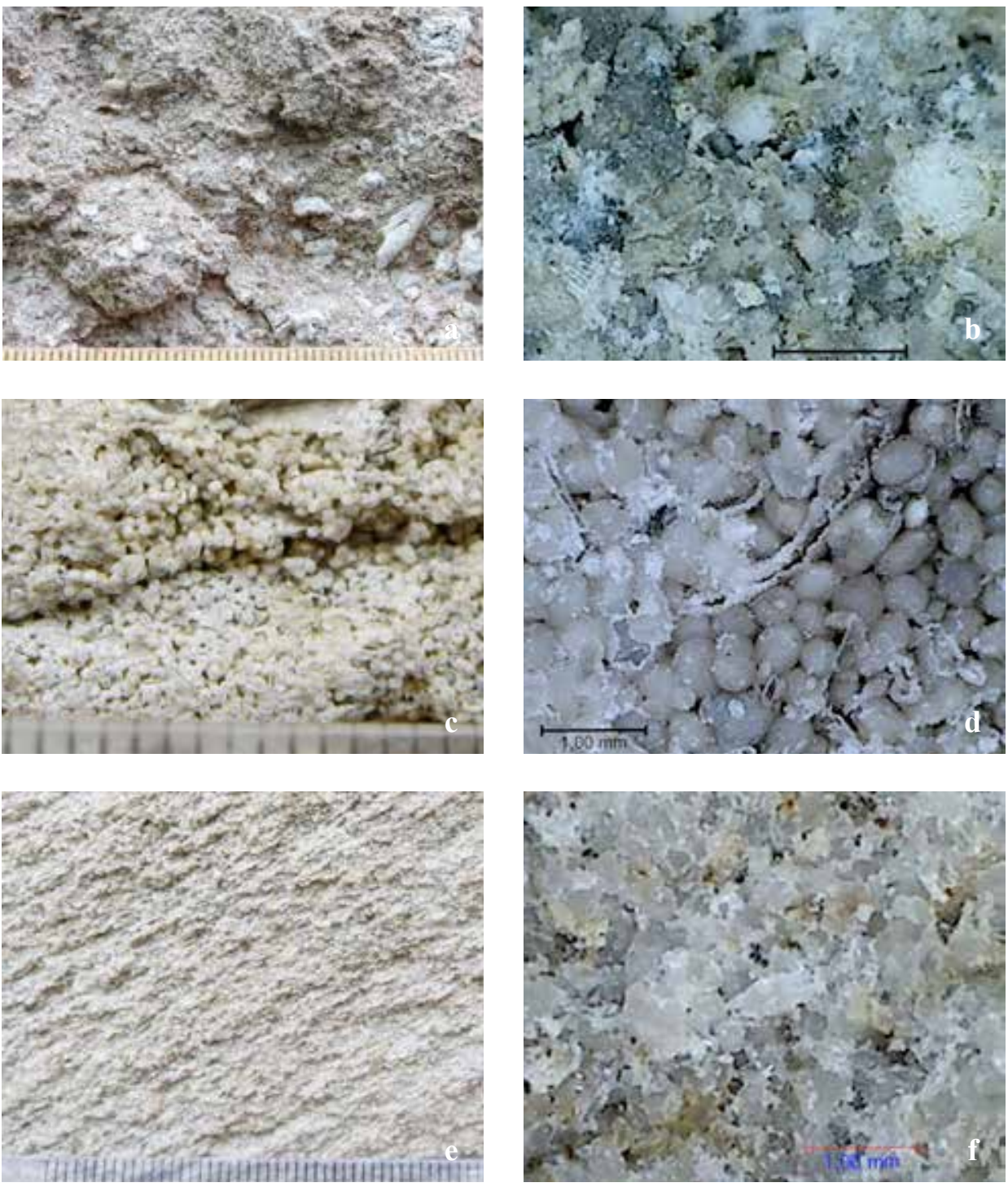

Obr. 8. Makroskopické a mikroskopické snímky kameňov Kostola sv. Mikuláša. a-b - hybridný pieskovec; c-d - oolitický vápenec; e-f- kremenný pieskovec. Foto D. Pivko.

Abb. 8. Makroskopische und mikroskopische Aufnahmen von Steinen der Nikolauskirche. a-b - hybrider Sandstein; c-d oolithischer Kalkstein; e-f - Quarzsandstein. Foto D. Pivko.

nad Devínom. Jedna vzorka s vel'kým obsahom úlomkov lastúrnikov sa približuje zložením lumachelovému vápencu, čiže vápencu zloženému takmer zo samých lastúr či ulít. Lumachelové vápence sú hojné medzi Hainburgom a Hundsheimom.

Hybridné pieskovce (obr. 8a, b) až organogénne vápence

Hybridné pieskovce sú trojzložkové pieskovce so zhruba proporčným zastúpením fosílií, úlomkov karbonátov a úlomkov hornín s obsahom kremeňa a silikátov. Existuje vel’a prechodných typov od hybridných pieskovcov k organogénnym vápencom, v ktorých prevažujú fosílie 
nad úlomkami hornín. Hybridné pieskovce sú skôr do sivožltých odtieňov, lebo obsahujú vel’a úlomkov karbonátov sivej a žltej farby. Organogénne vápence sú skôr krémovej farby. Pieskovce i vápence majú zrná strednej $(0,35-0,5 \mathrm{~mm})$ až hrubozrnnej $(0,5-1 \mathrm{~mm})$ vel'kosti. Miestami sú rozptýlené klasty až niekol'ko milimetrov. Súčast'ou hornín sú karbonáty (sivé a žlté zrná vápencov a dolomitov), siliciklastické zrná (kremeň, kremenec - svetlosivé, metamorfované horniny - čierne a hrdzavé zrná) a fosílie (biele a svetlosivé zrná). $Z$ fosílií sa dali identifikovat' červené riasy, dierkavce (miliolidy, borelisy, elfídiá, miniaciny), úlomky ježoviek, lastúrnikov a machoviek. Medzi zrnami je základná hmota, kalcitový tmel a póry.

Miestom t’ažby hybridných pieskovcov a vápencov bol stredoveký kameňolom pri Devíne (Pivko 2011), kde sa t’ažili horniny bádenského veku. Vzorky z Podunajských Biskupíc majú celkovo menej klastického materiálu, ako ho je v dnešnom kameňolome (Pivko-HudáčkováHrabovský-Sládek-Ruman 2017). Vyplýva to z toho, že čím d’alej ideme od pobrežia mora, tým je menej materiálu z pobrežia a je viac fosílií. Časti d’alej od bývalého pobrežia sa odtažili v stredoveku, dnes zostali časti bližšie k podložiu (pobrežiu), tvoreného vápencami a kremencami. Jedna vzorka je svojím zložením blízka vápencom z plošiny Metzen nad Devínom.

\section{Lumachelové až organogénne vápence}

Svojím zložením sa odlišujú od predošlých bádenských vápencov a pieskovcov. Silne pórovité vápence s malým množstvom kalcitového tmelu obsahujú vel’a lastúrnikov, často vylúhovaných, d’alej riasové hlúzky a dierkavce nubekulárie. Charakter hornín a chýbanie úlomkov ježoviek napovedá na vápence sarmatského veku, ktoré sa vyskytujú v Hainburských vrchoch pri Wolfsthale a menej pri Hundsheime.

\section{Oolitické vápence (obr. 8c, d)}

Krémové až sivohnedé vápence sú zložené z prevahy vápnitých guličiek - ooidov, vel'kých okolo $0,3-0,5 \mathrm{~mm}$. V menšej miere sú prítomné vylúhované úlomky schránok mäkkýšov obalené kalcitovým tmelom, schránky dierkavcov, riasové hl'úzky a kremeň. V jednej vzorke je vel'ké množstvo lastúrnikov. Neogénne oolitické vápence (sarmatského veku) pochádzajú z okolia Wolfsthalu.

\section{Kremenný pieskovec (obr. 8e, f)}

Jeden nedokončený architektonický článok je vytesaný z krémovo-sivého kremenného pieskovca, ktorý je tvorený zo zrniečok sivobieleho až sivého kremeňa prevažne strednozrnnej vel'kosti. Obsahuje aj žltkasté (zvetrané živce?), málo hrdzavé zrná, sivé šupinky muskovitu a čierne zrná. Pieskovec je silne vápnitý, medzi zrnami je kalcitový tmel. Podobný pieskovec panónskeho veku sa t’ažil v Bernolákove. Určitá podobnost' je aj na panónske pieskovce z Edelstalu.

\section{Interpretácia a diskusia (tab. 1)}

Neopracované horniny pochádzajúce z kryštalinika Malých Karpát. Najbližšie k Podunajským Biskupiciam sa nachádzajú v oblasti Bratislavy. Odtial' mohli byt' dovezené lod’ami po prúde ramenami Dunaja, z ktorých mnohé tiekli ned’aleko Podunajských Biskupíc. Niektoré vzorky majú zaoblený tvar, takže sú to obliaky vytažené zo staroštvrtohorných štrkov, dávnych náplavov Dunaja, ktoré sa nachádzajú aj pod obcou.

Opracované horniny neogénneho veku pochádzajú z viacerých lokalít. Bud' sú primárne z kameňolomov alebo z rozoberaných rímskych stavieb (Pivko 2016). Počas rímskej doby v 1. až 4. storočí boli organogénne, riasové a lumachelové vápence z Hainburských vrchov medzi Hainburgom a Hundsheimom bežným a najbližším materiálom na opracované výrobky v Carnunte a okolí. Vzhl'adovo i kvalitou boli dost' premenlivé. Kvalitnejší materiál na ušlachtilejšie kamenárske a sochárske výrobky, napr. na náhrobníky, našli Rimania na severe Litavských vrchov, kde začali t'ažit' pórovité riasové vápence. V menšej miere boli využívané oolitické a organogénne vápence $\mathrm{z}$ Wolfsthalu. 


\begin{tabular}{|c|c|c|c|c|c|c|c|c|c|c|}
\hline 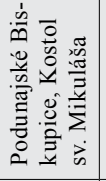 & 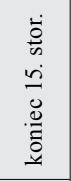 & 1 & 1 & 1 & 1 & 1 & 1 & $a$ & $a$ & $a$ \\
\hline 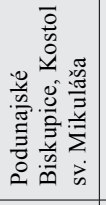 & 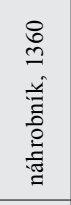 & 1 & 1 & 1 & 1 & 1 & 1 & $a$ & 1 & 1 \\
\hline 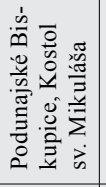 & 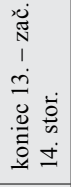 & n & $\tilde{\tilde{n}}$ & $\tilde{i}$ & $\hat{i s}$ & $\dot{i n}$ & $\tilde{i}$ & $a$ & 1 & 1 \\
\hline 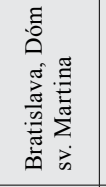 & 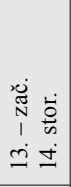 & $n$ & $\tilde{i}$ & $\tilde{i}$ & $\tilde{\dot{s}}$ & & $\tilde{i}$ & $a$ & 1 & 1 \\
\hline 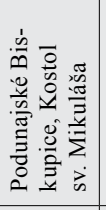 & 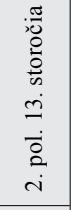 & an & $\tilde{\tilde{n}}$ & $\tilde{\dot{n}}$ & 1 & $\tilde{i n}$ & 1 & a. & 1 & 1 \\
\hline 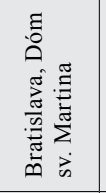 & 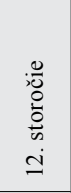 & n & 1 & $\dot{\tilde{n}}$ & 1 & 1 & 1 & 1 & 1 & 1 \\
\hline 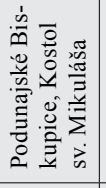 & 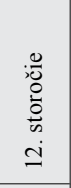 & is & in & $\ddot{i n}$ & $\ddot{i s}$ & $\ddot{i n}$ & $\hat{n}$ & 1 & 1 & 1 \\
\hline 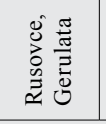 & $\begin{array}{l}\dot{a} \\
\dot{5} \\
\dot{+} \\
\dot{i} \\
\end{array}$ & $a$ & $a$ & $a$ & $a$ & $a$ & $a$ & 1 & 1 & 1 \\
\hline 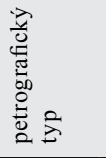 & & 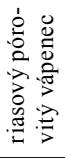 & 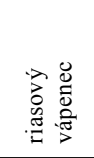 & 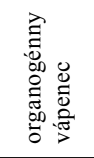 & 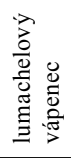 & 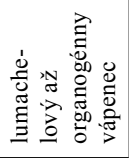 & 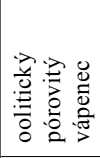 & 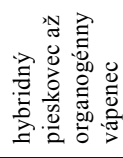 & 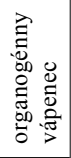 & 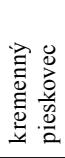 \\
\hline $\begin{array}{l}\stackrel{\frac{\pi}{3}}{\pi} \\
\frac{\pi}{0}\end{array}$ & & 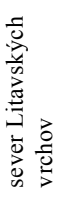 & 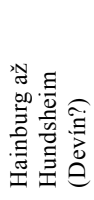 & 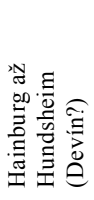 & 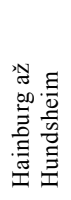 & 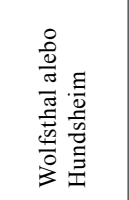 & 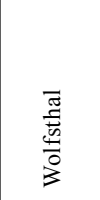 & 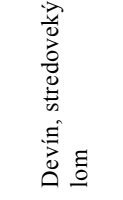 & 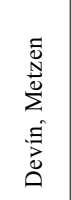 & 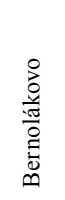 \\
\hline
\end{tabular}


Tieto typy hornín sa dajú nájst' v rímskych pamiatkach v Petronell-Carnunte, v Bad Deutsch Altenburgu a v Rusovciach (Gerulate). Sekundárne sú umiestnené v stredovekých kostoloch, hradoch a opevneniach (Bratislava, Bernolákovo, Boldog, Deutsch Jahrdorf, Hainburg, Petronell-Carnuntum, Bad Deutsch Altenburg, Berg, Hollern, Rohrau, Schönabrunn a Wildungsmauer; Pivko 2016). Známe je použitie rímskej stély v románskej fáze kostola v Boldogu (Kolník 2000).

Najbežnejším materiálom pre opracované výrobky v Gerulate boli práve riasové vápence zo severu Litavských vrchov a organogénne, riasové a lumachelové vápence $\mathrm{z}$ Hainburskych vrchov, $v$ menšej miere i oolitické a organogénne vápence $\mathrm{z}$ Wolfsthalu. Obdobné horniny sme identifikovali revíziou vzoriek archeologického výskumu v lodi Katedrály sv. Martina, kde boli odkryté časti predchodcov katedrály z 12. a 13. storočia (Holzer 2004). Nepredpokladáme, že by sa do Bratislavy vozili z Gerulaty, bolo by to proti hlavnému prúdu Dunaja. Skôr to bolo z neznámej rímskej stavby na bratislavskom hradnom vrchu, prípadne z Carnunta. Zloženie hornín je podobné ako na iných rímskych stavbách v Carnunte a okolí. Rovnaký zdroj materiálu mohol byt' aj pre Kaplnku sv. Jakuba z 13. storočí, kde sa našiel článok vytesaný z riasového vápenca zo severu Litavských vrchov. Z dlhoročného výskumu pamiatok v širokom okolí Bratislavy aj v pril'ahlom Rakúsku vyplýva, že tento typ vápenca nebol používaný v okolí Bratislavy ako primárny v období stredoveku. Tým dokazuje, že musí pochádzat' z rímskych pamiatok.

Kostol sv. Mikuláša v Podunajských Biskupiciach má podobnú históriu použitia kameňov ako stavby v okolí. Spomínané typy hornín pôvodne t’ažené Rimanmi v Hainburgu až Hundsheime, vo Wolfsthale a na severe Litavských vrchov sa nachádzajú sekundárne použité v stavebných etapách z polovice 12. storočia a $\mathrm{z}$ druhej polovice 13. storočia. Kameň bol pravdepodobne privezený lod’ami z Gerulaty po ramenách Dunaja, ktoré sa menili po každej vel'kej povodni. Odhadujeme vzdialenost' väčšinou proti prúdu od 10 do $15 \mathrm{~km}$. Iným zdrojom by mohla byt' neznáma rímska stavba na Bratislavskom hradnom vrchu s dovoznou vzdialenostou po prúde Dunaja nad $10 \mathrm{~km}$. Tento zdroj bol pravdepodobne využívaný v Bratislave. Pre kostol v Podunajských Biskupiciach mohol byt' prípadne použitý materiál z Carnunta. Po Dunaji by to bolo ca $30 \mathrm{~km}$. Na konci 13. a začiatku 14. storočia predstavuje „rímsky“ materiál v Kostole sv. Mikuláša už len čast' použitého materiálu. Zrejme bol recyklovaný zo zbúranej staršej stredovekej etapy. O rímskom pôvode mnohých kamenných kvádrov svedčí aj rímsky nápis na jednom z nich, opracovanie zubatým dlátom, ktoré nie je známe zo stredoveku, i zachovaný fragment mal'by.

Hybridné pieskovce až organogénne vápence z Devína sa v Podunajských Biskupiciach objavujú až s výstavbou sakristie a vrchnej časti presbytéria na konci 13. až začiatku 14. storočia. Dovozná vzdialenost' po Dunaji je ca $20 \mathrm{~km}$. Zhruba v tom istom období boli hybridné pieskovce použité i v predchodcovi Katedrály sv. Martina, v 13. storočí v Kaplnke sv. Jakuba.

Ojedinelým materiálom v gotickej etape (začiatok 14. storočia) je pieskovec, pravdepodobne z Bernolákova, ktoré je vzdialené len 10 až $15 \mathrm{~km}$ po ramenách Dunaja. Do Podunajských Biskupíc si kamenný blok možno priviezol so sebou tamojší kamenár. Nedokončená práca časti okna v zásype hlavného gotického oltára môže svedčit’ o nekvalitnej práci kamenára alebo nevhodnom materiáli, inom ako ostatné výrobky.

\section{Geofyzikálny prieskum}

V priebehu rokov 2016 a 2017 boli v Kostole sv. Mikuláša realizované topografické a geofyzikálne merania pomocou georadaru (GPR - Ground Penetrating Radar) pre účely archeologického výskumu. Geofyzikálny prieskum má neinvazívny charakter, je výhodný pre svoju časovú nenáročnost' a efektivitu. Metóda GPR využiva meranie odrazov vysielaných elektromagnetických vín do podložia na zobrazenie stavby skúmaného prostredia pod povrchom.

GPR meranie bolo realizované pomocou pristroja GSSI SIR-3000 (USA) s $400 \mathrm{MHz}$ anténou. Prebiehalo v paralelných profiloch jedným smerom s $0,3 \mathrm{~m}$ rozstupom. Topografické merania boli realizované pomocou totálnej stanice Trimble M3 v exteriéri kostola spolu s jeho širším 


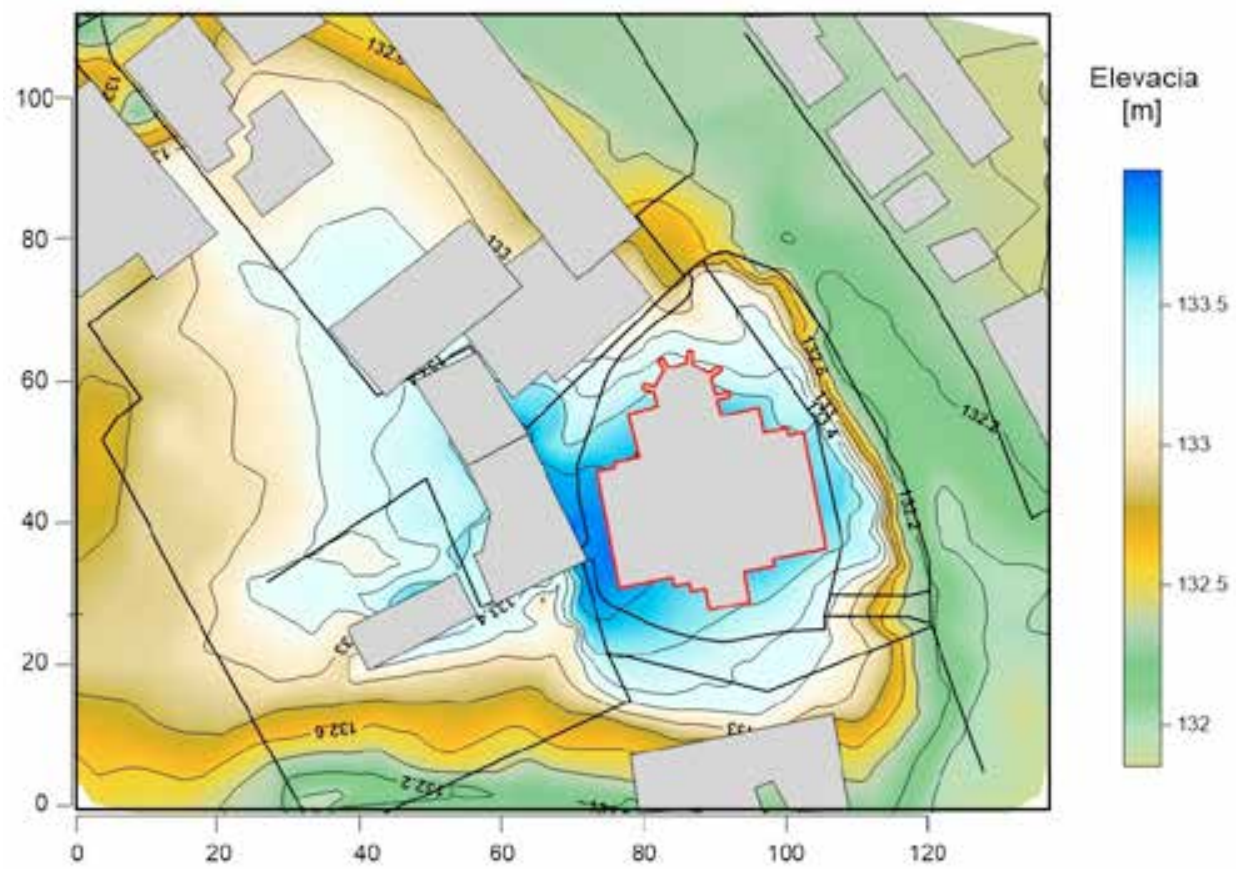

Obr. 9. Digitálny model terénu (DTM) okolia skúmanej lokality v lokálnych súradniciach.

Abb. 9. Digitales Geländemodell (DTM) der Umgebung der untersuchten Fundstelle in den lokalen Koordinaten.

okolím. Výsledky topografického merania boli spracované programom Surfer (Golden software, USA) a sú zobrazené vo forme digitálneho terénneho modelu na obr. 9.

Meranie v exteriéri kostola sa zameriavalo na okolie presbytéria a lode o celkovej výmere ca $600 \mathrm{~m}^{2}$ (obr. 10). V interiéri kostola bol prieskum realizovaný na celkovej ploche $63 \mathrm{~m}^{2}$, $\mathrm{v}$ priestoroch presbytéria $(\mathrm{ca} 6 \times 8 \mathrm{~m})$ a sakristie $(\mathrm{ca} 3 \times 5 \mathrm{~m})$.

V exteriéri kostola sú výsledky GPR merania do značnej miery ovplyvnené koreňovým systémom stromov a inžinierskych sietí. Vo výsledkoch boli z viacerých anomálií detegované dve anomálie s archeologickým významom. Anomália (I) v SZ časti areálu kostola je interpretovaná ako zahíbený objekt obdĺžnikového tvaru s rozmermi ca $10 \times 2 \mathrm{~m}$, v hĺbke ca od 0,5 do $1 \mathrm{~m}$. Druhá anomália (II) nachádzajúca sa pri vchode do sakristie je tvorená výraznými reflexami usporiadanými nad sebou s dobre definovatel'ným obrysom od híbky ca 0,6 do 2,0 m a šírkou $1 \mathrm{~m}$. Poukazuje na možnost' existencie pochovaného muriva $\mathrm{v}$ danom mieste (obr. 11). V priestore kontaktu múrov (III) vonkajších stien sakristie, presbytéria a oporného pilieru existuje predpoklad pokračovania pochovaného najstaršieho muriva identifikovaného $\mathrm{v}$ archeologickom výskume. Tento priestor bol však narušený odtokovým potrubím napájajúcim sa na hlavnú vetvu odtoku. To ovplyvnilo výsledky merania $\mathrm{z}$ daného miesta. V GPR profile sú viditel'né výrazné reflexy súvisiace s daným potrubím. Priestor záujmu nachádzajúci sa pod potrubím sa nedá interpretovat' (obr. 12).

V interiéri kostola boli vo výsledkoch GPR merania identifikované anomálie s archeologickým významom v priestore presbytéria. V strednej časti meranej plochy sa nachádza lineárna anomália (IV) prechádzajúca od SZ steny presbytéria naprieč meranou plochou, kde sa približne v jej strede stráca. Prejavuje sa výraznými reflexami s dobre ohraničeným tvarom (obr. 13). Táto anomália bola interpretovaná ako pochované murivo, ktoré bolo potvrdené aj archeologickým výskumom. Ďalšie anomálie (V) vytvárajú zónu pozdíž obvodového múru presbytéria. Majú 


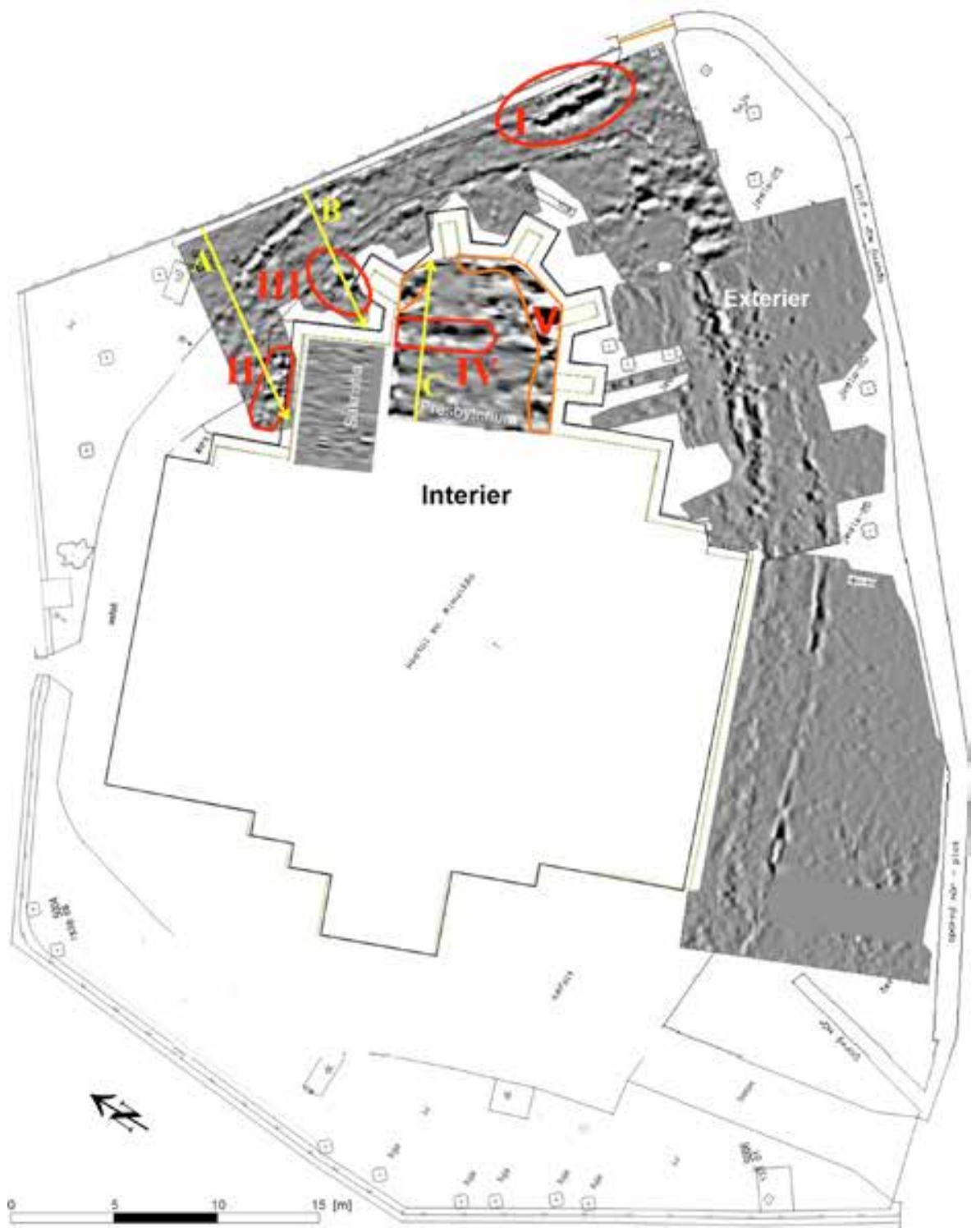

Obr. 10. Plán lokality s výsledkami GPR merania. Horizontálny GPR rez z híbky $100 \mathrm{~cm} s$ vyznačenou polohou vybraných GPR profilov (žltá farba) a s anomáliami archeologického významu (červená farba).

Abb. 10. Plan der Fundstelle mit Ergebnissen der GPR-Messung. Horizontaler GPR-Schnitt aus einer Tiefe von $100 \mathrm{~cm}$ mit gekennzeichneter Lage ausgewählter GPR-Profile (gelbe Farbe) und mit Anomalien von archäologischer Bedeutung (rote Farbe).

rôznu híbku a nepravidelný tvar. Môžu mat' rôzny pôvod a ich interpretácia nie je jednoznačná. Merania v sakristii boli realizované v dostupných priestoroch. Vo výsledkoch boli identifikované inžinierske siete, rozvody v plytkej híbke. Okrem nich sú viditel'né len slabé rozhrania, nevýrazné zmeny v dátach, ktoré sa nedajú s určitost'ou interpretovat'. 


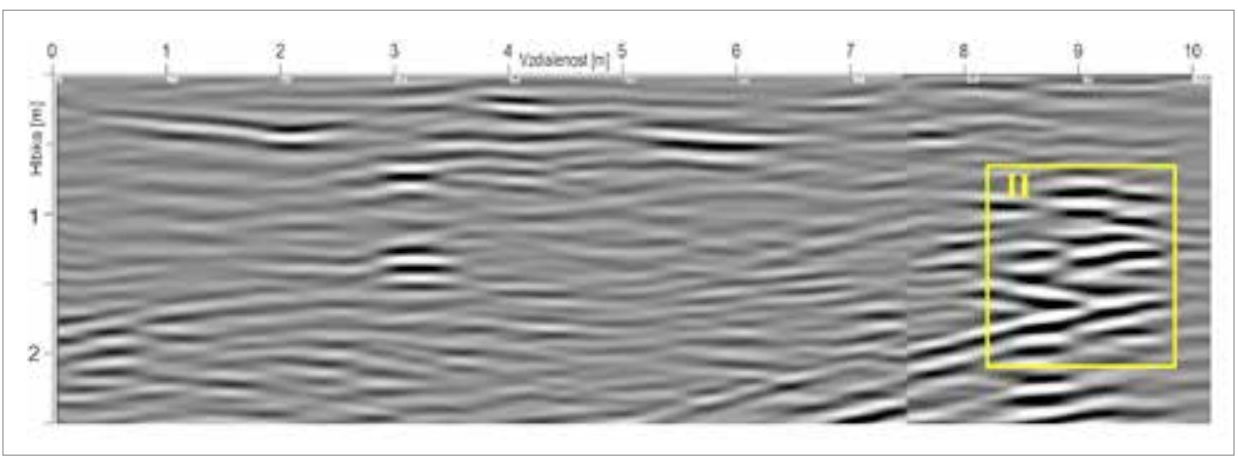

Obr. 11. GPR profil A s vyznačenou anomáliou II.

Abb. 11. GPR-Profil A mit gekennzeichneter Anomalie II.

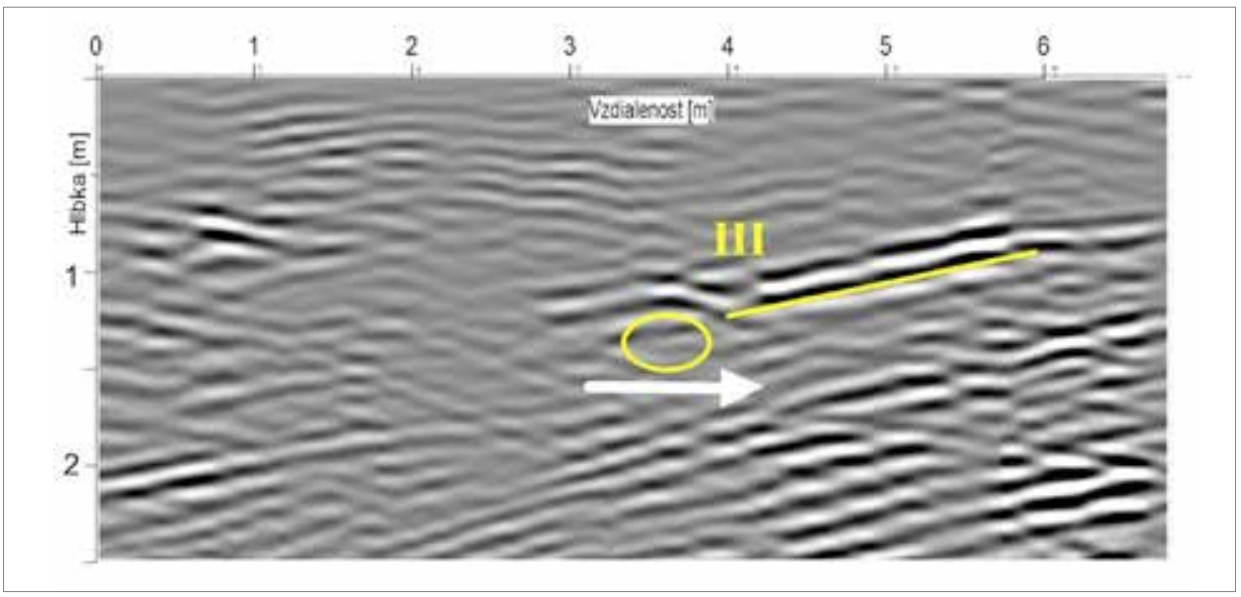

Obr. 12. GPR profil B s vyznačenou anomáliou III - odtokové potrubie, biela šípka označuje miesto archeologického záujmu. Abb. 12. GPR-Profil B mit gekennzeichneter Anomalie III - Abwasserrohr, der weisse Pfeil bezeichnet einen Ort von archäologischem Interesse.

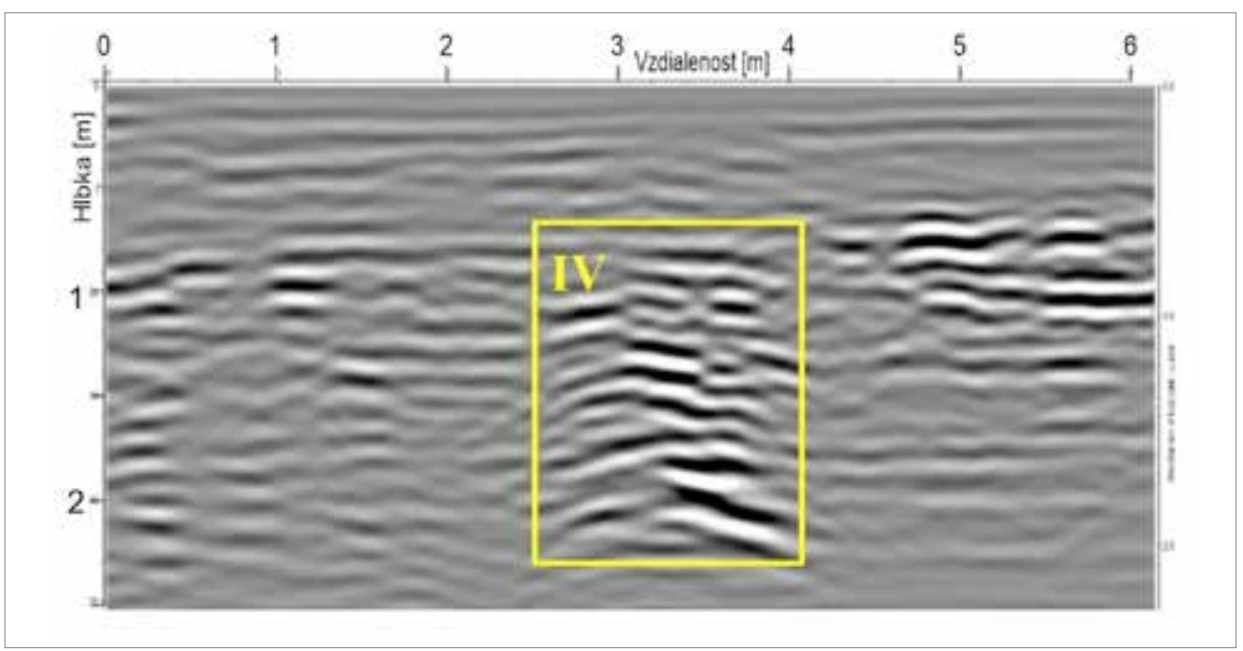

Obr. 13. GPR profil C s vyznačenou anomáliou IV - pochované murivo.

Abb. 13. GPR Profil C mit gekennzeichneter Anomalie IV - begrabenes Mauerwerk. 
Podmienky merania na lokalite boli obmedzené, skúmaný priestor je značne zastavaný, jeho podložie prešlo viacerými výraznými zásahmi a zmenami. Nachádza sa tu viacero inžinierskych sietí. Napriek tomu sa podarilo identifikovat' niekol'ko štruktúr archeologického významu. $\mathrm{V}$ priestoroch presbytéria bolo identifikované pochované murivo a bol zmapovaný jeho d’alší priebeh. V exteriéri pred sakristiou bola detegovaná štruktúra, pravdepodobne pochované murivo, ktoré môže byt' záujmom d’alšieho archeologického výskumu.

\section{Závery}

Predkladaná štúdia rieši problém identifikácie štyroch najstarších stavebných horizontov dnešného Kostola sv. Mikuláša v Podunajských Biskupiciach. Počiatky existencie sakrálnej stavby vychádzajú výlučne zo záverov archeologického výskumu. Prvú fázu spájame s existenciou cintorína, uprostred ktorého by mala stát prvá sakrálna stavba. Cintorín je datovaný nálezmi esovitých záušníc do obdobia od prelomu 10.-11. až prvej polovice 11. storočia. K uvedenej stavbe by mohla patrit' podlaha č. 8 zachytená v S4/16. Prvý kostol pravdepodobne stál v superpozícii s dnešným presbytériom (ca 11. storočie).

Súčasná situácia v Bratislave zodpovedá nálezom z Podunajských Biskupíc. Starší horizont hrobov z radových pohrebísk v línii Staromestská-Kapitulská, Hlavné námestie-Sedlárska a Nám. SNP je datovaný na záver 10. až do 11. storočia. Všetky tri enklávy ležia v blízkosti komunikácií a vodného toku. V nariadeniach uhorských král'ov sa v priebehu celého 11. storočia stretávame s príkazom pochovávat' pri kostoloch (Lesák 2004, 52-53). Mladší horizont pochovávania (prelom 11.-12. storočia) v Bratislave súvisí s výstavbou prvých sakrálnych stavieb na hrade (Kostol Najsvätejšieho Spasitel'a) a v podhradí (Rotundy sv. Vavrinca a sv. Mikuláša) a so zakladaním cintorínov v ich tesnej blízkosti (Hoššo-Lesák 1996, 241-246; Lesák 2004, 53).

Ako relikt druhej stavebnej fázy v Podunajských Biskupiciach možno označit rozšírený základ zachytený pod severozápadnou stenou presbytéria. Jej pôdorys je však nejasný, nakol'ko $\mathrm{v}$ sonde S4/16 sa murivo stáča smerom na sever, pod oporným pilierom a jeho d'alšie pokračovanie nebolo nateraz doložené. Datovanie uvedenej fázy možno zdola ohraničit' porušením existujúceho cintorína a zvrchu objektom 11/18, ktorý základ pret’al. Kladieme ho rámcovo do 11. storočia (?). V druhej polovici 12. storočia bola k staršiemu kostolu pristavaná lod' v rozsahu dnešného trojlodia. Začiatkom 13. storočia došlo k zbúraniu starého kostola asi po úroveň objektu 11/18 (rovný uzáver?). V prípade objektu 11/18 nie je úplne doriešený jeho rozsah ani interpretácia. Možno ho pokladat' za súčast' štvrtej stavebnej fázy. Zvrchu je jeho existencia ohraničená položením podlahy č. 4 (S5/18; v sondách $\mathrm{S} 1-\mathrm{S} 2 / 15$ dlážka č. 4; v sonde S3/16 podlaha č. 5), ktorá pravdepodobne zjednotila celú plochu dnes stojaceho presbytéria. K uvedenej zmene došlo v 13. storočí, čiže existenciu objektu 11/18 predpokladáme v období 12. storočia. Koncom 13. až začiatkom 14. storočia bolo postavené polygonálne presbytérium, ku ktorému pred dokončením pristavali dnešnú sakristiu. Presbytérium bolo zaklenuté v polovici 14. storočia. Posledné vel'ké úpravy - nový krov nad celým kostolom (datovaný 1492) ukončil stredoveký stavebný vývoj Kostola sv. Mikuláša.

Príspevok vznikol rámci riešenia grantového projektu 1/0827/16 agentúry VEGA.

\section{Literatúra}

BOTEK, A.-ERDÉLYI, R.-PAULINY, P.-VACHOVÁ, B., 2015: Rímskokatolícky kostol sv. Mikuláša v Podunajských Biskupiciach - presbytérium (Architektonicko-historický výskum a návrh obnovy I. etapa), rkp. ulož. v dokumentácii Farského úradu Bratislava-Podunajské Biskupice.

- 2016: Rímskokatolícky kostol sv. Mikuláša v Podunajských Biskupiciach. (Architektonicko-historický výskum a návrh obnovy), rkp. ulož. v dokumentácii Farského úradu Bratislava-Podunajské Biskupice. 
- 2018: Kostol sv. Mikuláša v Bratislave-Podunajských Biskupiciach - nové poznatky o stavebnom vývoji, Pamiatky a múzeá 67, č. 4, 22-27.

ČAPLOVIČ, P., 1954: Slovanské pohrebište v Nitre pod Zoborom, SlArch II, 5-50.

FUSEK, G., 2012a: Chronologische Fragen der Nitraer Gräberfelder des 10.-11. Jahrhunderts: das Fallbeispiel Nitra-Šindolka. In: Die Archäologie der frühen Ungarn. Chronologie, Technologie und Methodik. RGZM - Tagungen. Band 17 (Bendeguz, T., Hrsg.), 89-112. Mainz.

- 2012b: Beitrag zur Typologie der S-förmigen Schlafenringe. In: Thesaurus Avarorum - Régeszeti tanulmányok Garam Éva tiszteletére (Vida, T., ed.), 803-812. Budapest.

HANULIAK, M.-REJHOLCOVÁ, M., 1999: Pohrebisko v Čakajovciach (9.-12. storočie), vyhodnotenie. Bratislava.

HARMADYOVÁ, K.-DIVILEKOVÁ, D., 2011: Výskumná správa z archeologického výskumu „Rímskokatolícka fara a pastoračné centrum, I. etapa, Bratislava - Podunajské Biskupice, okr. Bratislava, parc. č. 6, 7/1, 1/2, 8 a 2619/1“, rkp. ulož. v dokumentácii Farského úradu Bratislava-Podunajské Biskupice.

HOLZER, R., 2004: Inžiniersko-geologický výskum. In: Dóm sv. Martina v Bratislave: archeologický výskum 2002-2003 (Štefanovičová, T., ed.), 62-70. Bratislava.

HORVÁTH, V., 1990: Bratislavský topografický lexikon. Bratislava.

HOŠŠO, J.-LESÁK, B., 1996: Archeologický výskum predrománskej rotundy a karnera zaniknutej osady sv. Vavrinca v Bratislave - Die archäologische Erforschung der vorromanischen Rotunde und des Karners in der untergegangenen Siedlung des Hl. Vavrinec/Laurenz in Bratislava, AH 21, 241-251.

KOLNÍK, T., 2000: Stéla z Boldogu - najstarší náhrobný nápis na Slovensku, Pamiatky a múzeá 49, č. 3, $20-21$.

LESÁK, B., 2004: Vel'komoravské a povel'komoravské obdobie, 9.-11. storočie. In: Z najstarších dejín Bratislavy, 51-56. Bratislava.

PIVKO, D., 2011: Historický kameňolom litavských vápencov v Devíne pri Bratislave, Forum urbes medii aevi VI, 204-211.

- 2016: The origin of the material for Roman worked stones in the vicinity of Bratislava. In: Akten der 3. Österreichischen Römersteintagung, Amt der NÖ Landesregierung, 135-142. Bad Vöslau.

PIVKO, D.-HUDÁČKOVÁ, N.-HRABOVSKÝ, J.-SLÁDEK, I.-RUMAN, A., 2017: Palaeoecology and sedimentology of the Miocene marine and terrestrial deposits in the "Medieval Quarry" on Devínska Kobyla Hill (Vienna Basin), Geological Quarterly 61, 3, 549-568.

POLLA, B.-VALLAŠEK, A., 1991: Archeologická topografia Bratislavy. Bratislava.

REJHOLCOVÁ, M., 1974: Pohrebisko z 10.-12. storočia v Nových Zámkoch, SlArch XXII, 435-464.

- 1975: Výskum pohrebiska z 11. storočia v Čakajovciach. In: AVANS 1974, 87-89. Nitra.

- 1976: Pohrebisko z 10. a 11. storočia v Hurbanove - Bohatej, SlArch XXXIV, 191-234.

- 1995: Pohrebisko v Čakajovciach (9.-12. storočie), analýza. Nitra.

SMOLÁKOVÁ, M., 2006: K ikonografii sv. Juraja v stredovekom umení na Slovensku (Nástenné mal'by kostola v Podunajských Biskupiciach) - Zur Ikonographie deshl. Georg in der mittelalterlichen Kunst der Slowakei. Die Wandmalereien der Kirche in Podunajské Biskupice, AH 31, 433-442.

SPS: Súpis pamiatok na Slovensku. Zv. II. Bratislava 1968.

ŠIMONČIČOVÁ KOÓŠOVÁ, P., 2016: Výskumná dokumentácia z archeologického výskumu na stavbe „Rímskokatolícky kostol sv. Mikuláša v Podunajských Biskupiciach v Bratislave na Vetvárskej ulici, č. ÚZPF 342/1. Pamiatková obnova kostola, I. etapa“, rkp. ulož. v dokumentácii MÚOP, inv. č. 1723.

- 2017: Výskumná dokumentácia z archeologického výskumu na stavbe „Rímskokatolícky kostol sv. Mikuláša v Podunajských Biskupiciach v Bratislave na Vetvárskej ulici, č. ÚZPF 342/1. Pamiatková obnova kostola“, rkp. ulož. v dokumentácii MÚOP, inv. č. 1746.

VYSVETLIVKY, 2012: Vysvetlivky ku geologickej mape regiónu Malé Karpaty 1 : 50000 (Polák, M., ed.). Bratislava.

\section{Zusammenfassung}

Lokalisierung des ältesten Sakralraumes in der Nikolauskirche in Bratislava - Podunajské Biskupice (Ergebnisse der archäologischen Grabung)

In den Jahren 2015-2018 wurde in der Nikolauskirche in Bratislava-Podunajské Biskupice eine archäologische Grabung durchgeführt. Ihr Ziel war es, die Bauphasen der Kirche zu erfassen und im untersuchten Raum den ältesten Sakralbau zu identifizieren, weswegen hauptsächlich 
im Presbyterium und in der Sakristei Sondierschnitte abgesteckt wurden. Gleichzeitig erfolgte eine architektonisch-historische und restauratorische Untersuchung, deren Ergebnisse sich einander ergänzten. Die vorliegende Studie widmet sich dem archäologisch erfassten Horizont des 11. bis 13. Jahrhunderts, d.h. bis zur Entstehung des gegenwärtigen Grundrisses der dreischiffigen Kirche mit polygonalem Presbyterium. Die Ergebnisse werden von einer petrographischen Analyse ergänzt, welche eine sekundäre Verwendung des älteren Baumaterials belegt, sowie durch die Ergebnisse einer geophysikalischen Untersuchung, welche eine der beobachteten Bauphasen identifizieren.

Kirchenherr der Nikolauskirche war bis zum Jahr 1912 der Graner Erzbischof, dem auch das dortige Dorf gehörte. Erstmals Erwähnung findet die Kirche im Jahr 1264 als Papst Urban IV. sie Kaplan Stefan Váncsai zur Schenkung machte. Im 16. Jahrhundert wurde das Dorf nach Erwerb von Privilegien zu einer landesherrlichen Stadt erhoben.

Die Identifizierung des ersten Sakralbaus an der Stelle der Nikolauskirche basiert ausschließlich auf den Schlussfolgerungen der archäologischen Grabung. Wir verbinden sie mit der Existenz eines entdeckten Friedhofs, der anhand der Funde von s-förmigen Schläfenringen in die Zeit der Wende des 10.-11. bis zur ersten Hälfte des 11. Jahrhunderts datiert wurde. Zu dem aufgeführten Bau könnte Fußboden Nr. 8 (Sondierschnitt S4/16) gehört haben. Die erste Kirche stand wahrscheinlich in Superposition zum heutigen Presbyterium (ca. 11. Jahrhundert).

Das unter der Nordwestmauer des Presbyteriums entdeckte verbreiterte Fundament dürfte ein Relikt der zweiten Bauphase sein. Ihr Grundriss ist unklar, da das Mauerwerk in Sondierschnitt S4/16 in Richtung Norden unter einen Stützpfeiler führt und seine Fortsetzung bisher nicht belegt wurde. Die Datierung des Mauerwerks kann von unten durch die Aufgabe des existierenden Friedhofs und von oben durch Objekt 11/18 begrenzt werden, welches das Fundament durchquerte. Wir legen sie grob in das 11. Jahrhundert (?). In der zweiten Hälfte des 12. Jahrhunderts wurde an die ältere Kirche ein Schiff im Umfang des heutigen Dreischiffs angebaut. Anfang des 13. Jahrhunderts wurde die Kirche wohl bis zur Ebene von Objekt 11/18 abgerissen. Der Umfang von Objekt 11/18 ist nicht vollständig geklärt. Wir nehmen an, dass es Bestandteil der vierten Bauphase war. Von oben wird seine Existenz durch die Verlegung des Fußbodens Nr. 4 (S5/18) begrenzt, der wohl die gesamte Fläche des heute bestehenden Presbyteriums vereinheitlichte. Das Objekt datieren wir in das 12. Jahrhundert. Ende des 13. bis Anfang des 14. Jahrhunderts wurde das polygonale Presbyterium errichtet, zu welchem vor dessen Fertigstellung noch die heutige Sakristei angebaut wurde. Zur Einwölbung des Presbyteriums kam es Mitte des 14. Jahrhunderts. Mit den letzten großen Arbeiten (Dachwerk über der gesamten Kirche aus dem Jahr 1492) wurde die mittelalterliche bauliche Entwicklung der Nikolauskirche abgeschlossen.

Der vorliegende Beitrag entstand im Rahmen des Förderprojektes 1/0827/16 der Agentur VEGA.

Mgr. Petra Šimončičová Koóšová, PhD., Mestský ústav ochrany pamiatok v Bratislave, Uršulínska 9, 81101 Bratislava, Slovenská republika, almos@post.cz

Doc. Ing. arch. Mgr. Andrej Botek, PhD., Ústav dejín a teórie architektúry a obnovy pamiatok Fakulty architektúry Slovenskej technickej univerzity v Bratislave, Nám. Slobody 19, 81245 Bratislava, Slovenská republika,andrej.botek@stuba.sk

Ing. arch. Róbert Erdélyi, PhD., Slovenské národné múzeum, Vajanského nábrežie 2, 81006 Bratislava, Slovenská republika, rb.erdelyi@gmail.com

Ing. arch. Pavol Pauliny, PhD., Ústav dejín a teórie architektúry a obnovy pamiatok Fakulty architektúry Slovenskej technickej univerzity v Bratislave, Nám. Slobody 19, 81245 Bratislava, Slovenská republika, pavol.pauliny@stuba.sk 
Ing. arch. Barbora Vachová, PhD., Slovenské národné múzeum, Vajanského nábrežie 2, 81006 Bratislava, Slovenská republika, barbora.vachova@gmail.com

Doc. RNDr. Daniel Pivko, PhD., Katedra geológie a paleontológie Prírodovedeckej fakulty Univerzity Komenského v Bratislave, Mlynská dolina, 84215 Bratislava IV, Slovenská republika,pivko@fns.uniba.sk

Mgr. Igor Murín, PhD., Katedra archeológie Filozofickej fakulty Univerzity Komenského v Bratislave, Gondova 2, 81499 Bratislava, Slovenská republika,igor.murin@uniba.sk 
